Review

\title{
RNA 2'-O-Methylation (Nm) Modification in Human Diseases
}

\author{
Dilyana G. Dimitrova, Laure Teysset and Clément Carré *(D) \\ Sorbonne Université, Institut de Biologie Paris Seine, Centre National de la Recherche Scientifique, \\ Transgenerational Epigenetics \& Small RNA Biology, Laboratoire de Biologie du Développement, \\ 75005 Paris, France; dilyana.dimitrova@sorbonne-universite.fr (D.G.D.); \\ laure.teysset@sorbonne-universite.fr (L.T.) \\ * Correspondence: clement.carre@sorbonne-universite.fr
}

Received: 17 December 2018; Accepted: 30 January 2019; Published: 5 February 2019

Abstract: Nm (2'-O-methylation) is one of the most common modifications in the RNA world. It has the potential to influence the RNA molecules in multiple ways, such as structure, stability, and interactions, and to play a role in various cellular processes from epigenetic gene regulation, through translation to self versus non-self recognition. Yet, building scientific knowledge on the $\mathrm{Nm}$ matter has been hampered for a long time by the challenges in detecting and mapping this modification. Today, with the latest advancements in the area, more and more $\mathrm{Nm}$ sites are discovered on RNAs (tRNA, rRNA, mRNA, and small non-coding RNA) and linked to normal or pathological conditions. This review aims to synthesize the $\mathrm{Nm}$-associated human diseases known to date and to tackle potential indirect links to some other biological defects.

Keywords: RNA modifications; 2'-O-methylation (Nm); human diseases; epitranscriptomics

\section{Introduction}

\subsection{What is $\mathrm{Nm} / \mathrm{2}^{\prime}-\mathrm{O}-$ Methylation?}

2'-O-methylation (or Nm, where $\mathrm{N}$ stands for any nucleotide) is a co- or post-transcriptional modification of RNA, where a methyl group $\left(-\mathrm{CH}_{3}\right)$ is added to the $2^{\prime}$ hydroxyl $(-\mathrm{OH})$ of the ribose moiety (Figure 1). 2'-O-methyl ribose can occur on any base and is an abundant and highly conserved modification found at multiple locations in transfer RNA (tRNA), ribosomal RNA (rRNA), and small nuclear RNA (snRNA) [1-3]. Nm is also present in a number of sites on messenger RNA (mRNA) [4] and at the 3 '- end of small non-coding RNAs (sncRNAs), such as microRNAs (miRNAs) and small-interfering RNAs (siRNAs) in plants [4-8], on Ago2 loaded si- and miRNAs in flies, and on PIWI-interacting RNAs (piRNAs) in animals $[9,10]$.

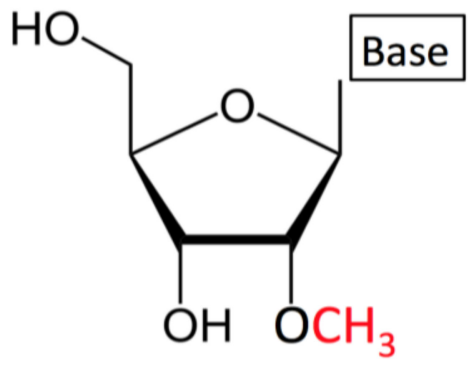

Figure 1. 2'-O-methylated ribonucleoside $(\mathrm{Nm}): \mathrm{A}-\mathrm{CH}_{3}$ group is replacing the $-\mathrm{H}$ at the position $2^{\prime}$ in the ribose moiety. This modification can appear on any nucleotide regardless of the type of nitrogenous base (Base). 
$\mathrm{Nm}$ has the potential to affect RNAs in multiple ways as it can increase their hydrophobicity, protect them from nuclease attacks [7,11], stabilize helical structures, and affect their interactions with proteins or other RNAs [12-14]. For example, Nm increases the thermodynamic stability of RNA:RNA base pairs and stabilizes A-form RNA duplexes [15-18]. The addition of Nm modification can also disrupt RNA tertiary structures [19] and inhibit RNA-protein interactions through steric effects [20,21] or by impacting hydrogen bonding [22,23].

\subsection{Nm Detection}

Detection of $\mathrm{Nm}$ modification has been a challenge for a long time. For example, classical biochemical strategies like liquid chromatography coupled with mass spectrometry (LC/MS) [24] and two-dimensional thin-layer chromatography (2D-TLC) $[25,26]$ can be extremely effective, but time and labor consuming. Multiple other methods exploit the capacity of $\mathrm{Nm}$ to protect the adjacent nucleotide bond from cleavage or to impede the reverse transcriptase at low dNTP concentrations. Most of these techniques, as well as their improved variations, have to compromise between sensitivity, difficulty of execution (e.g., requirement for large amount of starting material and purification of individual RNA populations), and applicability to only specific populations of RNAs (high-abundance RNAs) [4,27-33]. RiboMethseq is a high throughput sequencing method for mapping Nm modifications that is based on the protection given by Nm against alkaline hydrolysis [34-37]. It seems to bring together most of the other techniques' advantages. The main limitation of RiboMethseq is that it cannot be applied on short RNAs (<50nt) like sncRNA, for instance. Fortunately, a method based on the finding that Nm at the $3^{\prime}$ end of small RNAs can inhibit the activity of poly(A) polymerase was recently developed to detect such type of modification at this end position [38]. Although Nm-seq together with the RibOxi-seq methods [39] require bigger amounts of starting material than RiboMethSeq in general, they however all have the advantage of requiring a lower sequencing depth. For a recent comparison of sequencing-based Nm detection methods, see Reference [40].

It seems that we are finally well-equipped to detect and study $\mathrm{Nm}$ modification in a transcriptome-wide point of view.

\section{Nm in tRNA}

Transfer RNAs (tRNAs) are the most heavily modified RNA species and loss of certain modifications can cause deregulations in cellular processes and even diseases [41-43]. One of the most abundant modifications on them is $\mathrm{Nm}$. Its function depends on the localization and as a consequence can be associated with general stability of the tRNA structure and/or proper translation [16,44-46].

\subsection{FTSJ1 Identity and Conservation}

FTSJ1 (also known as MRX9, TRMT7, JM23) is a characterized human tRNA 2'-O-methyltransferase that targets the $\mathrm{C}_{32}$ and $\mathrm{N}_{34}$ positions in the anticodon loop of tRNA ${ }^{\text {Phe }}$ (Figure 2) and tRNA ${ }^{\text {Trp }}$. It actually belongs to a large phylogenetically conserved superfamily of RNA methyltransferases, the RRMJ/ fibrillarin superfamily [47,48]. FTSJ1 homologs in Escherichia coli and Saccharomyces cerevisiae are respectively FTSJ/RRMJ and TRM7 (tRNA methyltransferase 7).

Expression of the human FTSJ1 suppresses the severe growth defect of yeast TRM7D mutants [49]. In S. cerevisiae, TRM7 is the central component of a complex modification circuitry required for anticodon loop modification of target tRNAs. More concretely, TRM7 separately interacts with TRM732 and TRM734 partners to form $\mathrm{Cm}_{32}$ and $\mathrm{Nm}_{34}$ respectively, both of which are required on tRNA ${ }^{\text {Phe }}$ for efficient formation of a third modification, the wybutosine $(\mathrm{yW})$ at $\mathrm{m}^{1} \mathrm{G}_{37}$ by other proteins $[45,50,51]$. Impressively, the same circuitry appears to be conserved in the phylogenetically distant yeast Schizosaccharomyces pombe [49]. This extremely conserved circuitry might be further extended in eukaryotes since suppression of the growth defect of S. cerevisiae TRM7 $\Delta$ mutants by human FTSJ1 expression requires the function of TRM732 or its human homolog THADA to form 
$\mathrm{Cm}_{32}$ on $\mathrm{tRNA}{ }^{\text {Phe }}[49]$, and the formation of peroxywybutosine $\left(02 \mathrm{yW}_{37}\right)$ at $\mathrm{m}^{1} \mathrm{G}_{37}$ is also affected in humans lacking FTSJ1.

Interestingly, FTSJ1 has two conserved paralogs: FTSJ2 (mitochondrial rRNA methyltransferase 2 [Mrm2] in S. cerevisiae) and FTSJ3 (suppressor of poly-A binding protein Pab1p (Spb1) in S. cerevisiae), they however target different RNAs: $21 \mathrm{~S}$ rRNA [52,53] and 25S rRNA [54,55], respectively. Finally, the bacteria ancestor of those three proteins FTSJ/RRMJ is an RNA-binding heat shock protein that targets the $23 \mathrm{~S}$ ribosomal RNA [47]. FTSJ2 and FTSJ3 are briefly discussed in the next chapters.

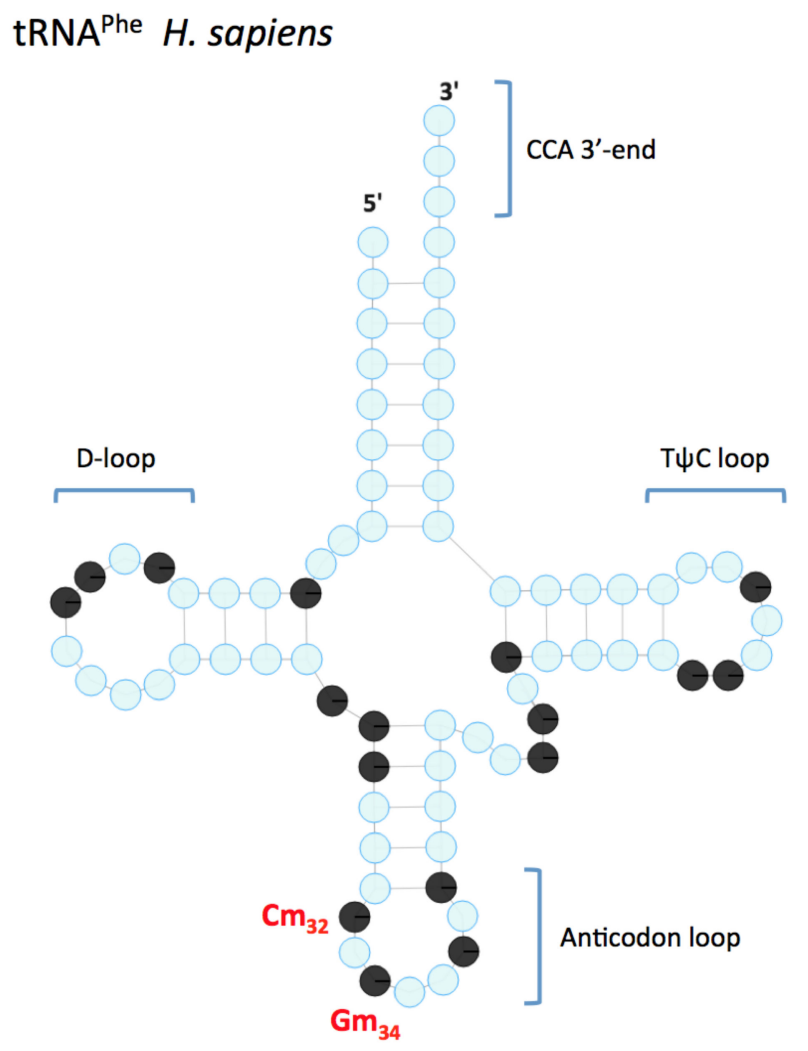

Figure 2. Representation of the mature human $\mathrm{tRNA}^{\text {Phe }}$ (76 nucleotides). The two Nm modifications in the anticodon loop, in $\mathrm{C}_{32}$ and $\mathrm{G}_{34}$, are placed by the $2^{\prime}$-O-methyltransferase FTSJ1 and are annotated in red. Blue circles are for non-modified nucleotides, black circles mean modified nucleotides (adapted from http://modomics.genesilico.pl/).

\subsection{FTSJ1 Link to Intellectual Disability}

Intellectual disability (ID), or previously known as mental retardation (MR), is characterized by non-progressive cognitive impairment and affects $1-3 \%$ of the general population. X-linked genes seem to play a predominant role in ID as there are $10 \%$ more male than female ID patients cases reported [56]. One third of the X-linked ID (XLID) conditions are syndromic (SXLID) and the other two thirds are non-syndromic (NSXLID). As NSXLID has no obvious and consistent phenotypes other than mental retardation (IQ $<70$ ), NSXLID conditions are clinically diverse and genetically heterogeneous disorders.

FTSJ1 gene is located on the small arm of chromosome X (Xp11.23), and accordingly, its loss of function has been identified as a cause for non-syndromic X-linked intellectual disability (NSXLID) [57-64]. Distinct alleles of FTSJ1 from six independent families and one microdeletion affecting FTSJ1 together with SLC38A5 (solute carrier family 38 member 5) are linked to NSXLID (see Table 1 and updated from Reference [65]). Also, novel FTSJ1 variations that appeared de novo in two other NSXLID patients are under investigation for further molecular details (Amélie Piton \& Elise Schaefer Hôpitaux Universitaire de Strasbourg, personal communication and Ambry Genetics 
company reported in Clinvar). Heterozygous loss-of-function mutations in females do not cause the disease, which is most probably due to inactivation of the affected X chromosome [61,63].

Table 1. FTSJ1 mutations associated with NSXLID (ss: splice site mutation, >: substitution, del: deletion, c.xxx: indicating the nucleotide ( $x x x)$ mutated on the gene coding DNA sequence (CDS), p.ZxY indicating that amino acid $\mathrm{Z}$ is changed by $\mathrm{Y}$ in the mutant and $\mathrm{x}$ indicates the AA position on the protein. HUS: Hôpitaux Universitaire de Strasbourg.

\begin{tabular}{|c|c|c|c|c|}
\hline FTSJ1 Allele & Family & Mutation/Location & Effect & Reference \\
\hline Ftsj1 $1 \Delta$ & $6(\mathrm{AU})$ & Deletion of FTSJ1 and SLC38A5 & Loss of FTSJ1 & [61] \\
\hline FTSJ1-ss & A3 & $\begin{array}{l}\text { c. } 121 \text { + 1delG, p.Gly41Valfs*10 } \\
\text { (IVS2, G DEL, + 1)/ Exon } 2\end{array}$ & $\begin{array}{l}\text { Significant reduction of FTSJ1 } \\
\text { mRNA level (NMD) }\end{array}$ & [59] \\
\hline $196 \mathrm{C}>\mathrm{T}$ & $\mathrm{P} 48$ & c.196C > T, p.Gln66* Exon 4 & $\begin{array}{l}\text { Almost undetectable FTSJ1 } \\
\text { transcripts (NMD) }\end{array}$ & [59] \\
\hline $655 \mathrm{G}>\mathrm{A}$ & MRX44 & $\begin{array}{l}\text { c.655G > A, } \\
\text { p.Glu191_Tyr218del/ Exon } 9\end{array}$ & $\begin{array}{l}\text { Loss of exon } 9 \text {, protein lacking } \\
28 \text { amino acids }\end{array}$ & [59] \\
\hline$A>G$ & MRX9 & $\begin{array}{l}\text { c.192-2A>G, p.Gly65Cysfs*18 } \\
\text { (IVS3AS, A-G, -2)/ Intron } 3\end{array}$ & Truncated protein & [60] \\
\hline $\mathrm{G}>\mathrm{A}$ & MRW06 & $\begin{array}{l}\text { c. } 571+1 \mathrm{G}>\mathrm{A} \text {, } \\
\text { p.Glu191Glyfs*44/ Intron } 8\end{array}$ & $\begin{array}{l}\text { Significant reduction of FTSJ1 } \\
\text { mRNA level (NMD) }\end{array}$ & [63] \\
\hline p.A26P & 7 & c.76G > C; p.Ala26Pro/ Exon 2 & Altered FTSJ1 protein function & [64] \\
\hline $\mathrm{A}>\mathrm{T}$ & de novo variation & $\begin{array}{l}\text { c.362-2A > T, p.? / Intron } 5 \text { of } \\
\text { trascrit NM_012280.3 }\end{array}$ & $\begin{array}{l}\text { Unknown (probable loss of exon } \\
6 \text { of transcript NM_012280.3 } \\
\text { causing a frameshift) }\end{array}$ & $\begin{array}{l}\text { Amélie Piton \& Elise Schaefer, } \\
\text { HUS, personal communication }\end{array}$ \\
\hline $\mathrm{Y}>\mathrm{N}$ & de novo variation & c.34T > A; p.Tyr12Asn/ Exon 2 & Deposited as pathogenic & $\begin{array}{c}\text { Ambry Genetics Clinvar NCBI } \\
{[66]}\end{array}$ \\
\hline
\end{tabular}

Today, FTSJ1 represents one of the strongest links between ID and a tRNA Nm modification gene. Consistent with the 2'-O-methyltransferase activity of FTSJ1 on tRNAs, it was reported that tRNA ${ }^{\text {Phe }}$ from two genetically independent lymphoblastoid cell lines (LCL) of NSXLID patients (family 6 and A3-see Table 1) with loss-of-function FTSJ1 mutations nearly completely lack $\mathrm{Cm}_{32}$ and $\mathrm{Gm}_{34}$ and

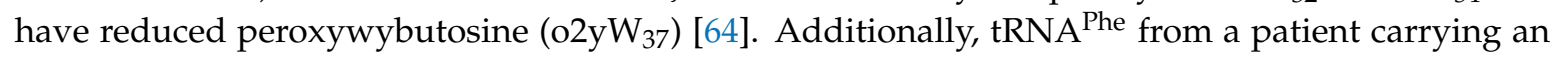
FTSJ1-p.A26P missense allele (family 7, Table 1) specifically lacks $\mathrm{Gm}_{34}$, but has normal levels of $\mathrm{Cm}_{32}$ and $\mathrm{o} 2 \mathrm{yW}_{37} . \mathrm{tRNA}{ }^{\text {Phe }}$ from the corresponding S. cerevisiae trm7-A26P mutant also specifically lacks $\mathrm{Gm}_{34}$, and the reason is not a weaker TRM7/TRM734 interaction. These results strongly link defective Nm modification of the tRNA anticodon loop to the neurodevelopmental disorder observed in all patients that carry an FTSJ1 mutation. It also points to the $\mathrm{Gm}_{34}$ of $\mathrm{tRNA}^{\text {Phe }}$ as a critical modification [64].

It is interesting to mention two more studies. First, three single-nucleotide polymorphisms (SNPs) in the FTSJ1 gene showed a positive association with NSXLID [62]. Second, another analysis on the same three SNPs even suggests that genetic variations in FTSJ1 are related to general cognitive ability, verbal comprehension, and perceptual organization in male individuals [67]. Although it is tempting to make a link between FTSJ1 alleles and human cognitive ability, more profound studies are needed to support that idea.

\subsection{Discussion on FTSJ1}

Today, it is well established that mutations in the human tRNA 2'-O-methyltransferase FTSJ1 cause NSXLID. FTSJ1 is an S-adenosyl methionine (SAM) family methyltransferase and it is known that SAM has the ability to cross the blood-brain barrier [68]. SAM also serves as the sole methyl donor for methylation processes in the central nervous system [68], which makes the link between FTSJ1 loss and a brain disease less surprising. So far, low cerebrospinal fluid levels of SAM have been observed in several neuropsychiatric and neurological disorders, including depression, brain ischemia, and dementia [68].

FTSJ1 is generally widely expressed [60], though all mutations identified in NSXLID patients result in relatively "mild phenotypes" (lack of malformations or systemic breakdowns) that are essentially brain specific: delayed speech, concentration and learning difficulties, autistic behavior, motor tics, seizures, and others. It is possible that the activity of FTSJ1 is most critical during brain development, 
which is supported by the relatively high expression of FTSJ1 mRNA in the foetal brain [59]. It is also plausible that brain structures are more sensitive to defects in the translation machinery than are other organs, although the amount of mature tRNA, nor the charging of the concerned tRNAs does not appear to be affected in case of FTSJ1 mutations [64] and the same is valid in S. cerevisiae [50]. However, and surprisingly, it has been shown recently by the same group that in S. cerevisiae, TRM7 mutants and the equivalent in $S$. pombe, the cells constitutively activated a robust general amino acid control (GAAC) response, acting through Gcn2 (general control nonderepressible 2), which senses uncharged tRNA [69]. Alternatively, another protein may partially compensate for the loss of FTSJ1, thereby preventing FTSJ1 mutations from causing more severe disorders. As we will discuss later in this review, Nm enzymes seem to demonstrate certain flexibility when it comes to their targets. Thus, Nm enzymes, other than FTSJ1, may, in addition to their known targets, partially methylate positions $\mathrm{C}_{32}$ and $\mathrm{N}_{34}$ of $\mathrm{tRNA}^{\text {Phe }}$ and $\mathrm{tRNA}^{\mathrm{Tr}}$. Finally, mRNA levels of Gcn2-dependent GAAC-regulated genes, CTH and GADD153, were not conclusively upregulated in cells carrying a mutation in FTSJ1.

Finally, FTSJ1 function seems to be crucial for normal brain development, but the dosage control of its expression may be equally important. Some studies describe cases of ID in which the patients carry duplication in the Xp11.23 region. Those duplications include FTSJ1, but also other genes associated with ID [70,71]. That makes it impossible at the moment to conclude whether a supplementary dose of FTSJ1 causes ID, the same way as the loss of FTSJ1.

The association of FTSJ1 with mental retardation highlights the importance of the Nm modification of RNAs, specifically in brain development and cognitive processes [65]. Current studies (including our group) aim to further characterize the mechanism of action of FTSJ1 and the associated to its lack-of-function molecular phenotypes. Preliminary data of our group showed an accumulation of specific tRNA fragments (tRFs) in mutants of the Drosophila homolog of FTSJ1, which is in accordance with the nuclease protection that Nm usually confers to modified nucleotides (Angelova et al., in prep). We are currently investigating this molecular phenotype and its potential conservation in humans as it may have a role in the abnormal brain development in the FTSJ1 patients.

\subsection{TRMT44 and Idiopathic Epilepsy}

TRMT44 is a putative $2^{\prime}$-O-methyluridine methyltransferase predicted to methylate residue 44 in tRNA ${ }^{\text {Ser }}$ [72]. Mutations in this gene were implicated in partial epilepsy with pericentral spikes, a novel mendelian idiopathic epilepsy. However, the underlying mechanisms that fails in those patients are currently unknown.

\section{3. $\mathrm{Nm}$ in rRNAs}

rRNAs are one of the most highly modified RNA species in the cell and definitely the ones that carry the most Nm modifications to date [34]. Those rRNA modifications are obtained at different stages of ribosome biogenesis and ensure efficiency and accuracy of the translation by stabilizing the rRNA scaffold [73,74]. There is also a certain heterogeneity in rRNA Nm modifications in disease that may alter ribosome function as a cause or as a consequence of the condition $[75,76]$.

\section{1. snoRNAs and Prader-Willi Syndrome}

The Nm modification at each rRNA site is regulated by box C/D small nucleolar RNAs (snoRNAs) in association with fibrillarin methyltransferase (see next chapter). The snoRNA serves as a guide due to its sequence complementarity to the target rRNA and fibrillarin ensures the methylation reaction [77-80].

The essentialness of rRNA Nm modifications for vertebrate development has been exemplified in zebrafish. Loss-of-function of any of the following three snoRNAs: SNORD26, SNORD44, and SNORD78, leads to severe morphological defects and/ or embryonic lethality in this animal model [81]. 
Even stronger is the link between certain C/D box snoRNAs and Prader-Willi syndrome (PWS), a complex human neurological disease characterized with mental retardation, low height, obesity, and muscle hypotonia [82-84]. In several independent studies, it was shown that PWS is caused by the loss of imprinted snoRNAs in locus 15q11-q13. Large deletions of this region underlie about $70 \%$ of the PWS cases [85], whereas duplication of the same region is associated with autism [86-88]. Locus 15q11-q13 contains numerous copies of two C/D box snoRNAs: SNORD115 (HBII-52) and SNORD116 (HBII-85) [89,90]. SNORD115 is believed to play key roles in the fine-tuning of the serotonin receptor (5-HT2C) pre-mRNA [91,92], while SNORD116 loss is thought to contribute in the etiology of the PWS $[89,93,94]$.

\subsection{Fibrillarin and Diseases: Identity and Conservation}

Fibrillarin (FBL) is a $34 \mathrm{kDa}$ nucleolar 2'-O-RNA methyltransferase and is located in the dense fibrillar component of the nucleolus to whom it owes its name. It associates with the U3 snoRNA, a C/D box family member and together they have been involved in the processing of precursor rRNAs [95].

Human FBL is $70 \%$ identical to yeast NOP1 and they are functional homologues since either human or Xenopus fibrillarin can complement (at least partially) a yeast nop1 mutant. In yeast, Nop1 is an essential nucleolar protein that is associated with small nucleolar RNA and is required for ribosome biogenesis [96]. Fibrillarin-like proteins also occur in the domain of Archaea [97]. FBL's function in ribosome biosynthesis appears to be maintained from the archaebacteria, which lack a nucleus, to Giardia, which contains a nucleus but lacks a prominent nucleolus, to higher mammals, which have both a nucleus and nucleolus $[98,99]$. This strong evolutionary conservation suggests a high importance for this enzyme in ribosome biogenesis.

Therefore, FBL is an essential nucleolar protein that catalyzes the 2'-O-methylation of ribosomal RNAs. In addition, FBL participates in pre-rRNA processing [95] and it was also reported that it could regulate rRNA transcription via the methylation of a glutamine residue of histone $\mathrm{H} 2 \mathrm{~A}$ in plants, yeast, and human $[100,101]$. It can be expected that changes in the level of FBL expression would seriously affect the translation process, but a direct confirmation of this hypothesis was received only recently [76]. The downregulation of FBL in human cells alters the intrinsic capacity of ribosomes to initiate translation from internal ribosome entry site (IRES) elements in a manner independent of translation initiation factors [76]. As a result, FBL can affect the course of some cellular processes. Indeed, FBL is required for early development in mice and zebrafish [102,103]. Fibrillarin mutant mice are non-viable due to a massive apoptosis in early embryos [102] and FBL gene depleted zebrafish are severely affected in the optic tectum and the eye due to impaired neural differentiation, and again, massive apoptosis [103]. FBL is also highly expressed in pluripotent embryonic stem cells of mice, where it regulates stem cell pluripotency [104].

Being implicated in such important biological processes, it comes as no surprise that FBL loss is associated with different disease conditions, some of which have been recently reviewed in Reference [105].

\subsection{Fibrillarin and Cancer}

Increased ribosome biogenesis is typically required in tumors in order to meet the high demand for protein production in the rapidly dividing cells [106,107]. As FBL plays a role in rRNA production, it is not surprising to find it overexpressed in different cancers [108-110]. It was demonstrated that FBL quantitative distribution is directly related to RNA polymerase I transcriptional activity (thus, to rRNA production), and is inversely related to cell doubling time in cancer cells [111]. More concretely, the knock-down of FBL in human prostate cancer lines suppresses proliferation and reduces clonogenic survival [108]. Also, FBL overexpression is associated with poor survival in patients with breast cancer and promotes cellular proliferation and resistance to chemotherapy of MCF7 breast cancer cells [109]. 
Interestingly, the tumor suppressor transcription factor p53 represses the expression of the $F B L$ gene by directly binding to it. The suppression of p53 expression in human mammary epithelial cells leads to modifications in the rRNA methylation pattern at the single nucleotide level, impairment of translational fidelity, and increased IRES-dependent translation of key cancer-related genes, such as IGF-1R, C-MYC, VEGF-A, and FGF1/2 [109]. On the other side, the oncogene transcription factor C-MYC binds to the $5^{\prime}$ - upstream region of the FBL gene and stimulates its expression $[108,112,113]$.

Curiously, a few older studies revealed that patients with hepatocellular carcinoma (HCC), gastrointestinal, lung, and ovarian cancers have autoantibodies to FBL [114-116]. One could imagine that their production is an attempt of the immune system to fight the tumor through eliminating a target that is advantageous for cancer cells. Even if those autoantibodies have also been found in systemic autoimmune diseases (see below), fibrillarin may still be an interesting anti-cancer target in drug design and therapies. Today, fibrillarin has not been exploited yet as an oncology target, but a very recent review emphasizes its potential as a therapeutic target that could lower the genotoxic effects of anti-cancer treatment [117].

\subsection{Fibrillarin and Autoimmune Diseases}

One of the most characteristic serologic features of systemic sclerosis (scleroderma, SSc), a collagen vascular autoimmune disease, is the occurrence of autoantibodies against nuclear and most notably against nucleolar antigens (antinucleolar antibodies (ANoA)) [118]. Multiple old studies have identified fibrillarin as the third major nucleolar scleroderma autoantigen [119-124] and have concluded that anti-fibrillarin is a marker for severe SSc [125]. Those ANoAs do not seem to affect the survival rate of patients with diffuse cutaneous systemic sclerosis, one of the most severe complications, and the events that initially trigger their production are not known [126,127]. However, and curiously, a case of a 22-year-old woman was successfully treated with long-term plasma exchange whose beneficial effect persisted for two years [128].

Anti-fibrillarin antibodies have been detected in a variety of connective tissue patients like the mixed connective tissue diseases (60\%), CREST syndrome (calcinosis, Raynaud phenomenon, esophageal dysmotility, sclerodactyly, and telangiectasia syndrome, 58\%), systemic lupus erythematosus $(39 \%)$, rheumatoid arthritis $(60 \%)$, and Sjogern's syndrome $(84 \%)$, in addition to SSc patients $(58 \%)[129,130]$. However, outside the connective tissue diseases spectrum, anti-fibrillarin antibodies are rarely seen.

Of course, in the case of autoimmune diseases, the development of autoantibodies against FBL is rather a consequence and not a cause of the pathology. Still, autoantibodies are expected to lead to a decrease in the protein levels of their target. It would be interesting to verify whether indeed FBL protein is less present in certain patient's tissues, as well as whether its targets lack Nm modifications, and look for related/correlated effects in terms of symptoms and aggravation of the disease.

\subsection{Fibrillarin: Possible Link to Other Diseases}

Among FBL's interaction partners is the survival of motor neurons (SMN) protein $[131,132]$. The SMN gene is the disease-causing gene of spinal muscular atrophy (SMA), a common and often fatal autosomal recessive disease, leading to progressive muscle wasting and paralysis as a result of degeneration of anterior horn cells of the spinal cord $[133,134]$. In human cell lines, the SMN protein localizes in gemini of Cajal bodies (gems), compartments frequently found near or associated with Cajal bodies (nonmembranous nuclear sub-organelles), in which FBL is found [135-138]. Among its other functions, SMN has been suspected to be involved in ribosome biogenesis [139], a cellular process in which FBL is strongly implicated. The exact role of SMN in SMA is not completely clear and it is unknown if its interaction with FBL is also involved. FBL immunofluorescence in Schwann cells revealed nucleolar segregation in a tellurium-induced demyelinating neuropathy rat experimental model [140]. It has not been excluded that FBL may play a role in that kind of disorder. 
Finally, a recent study shows evidence of altered 2'-O-methylation of rRNA in $28 \mathrm{~S}$ rRNA and increased levels of FBL expression in $\beta$-thalassemia trait carriers [141]. Today, thalassemia is the most important hematologic inherited genetic disease worldwide.

\subsection{FTSJ2 and Cancer}

Another enzyme involved in rRNA Nm modification is FTSJ2, one of the two paralogues of FTSJ1. As already mentioned, FTSJ2 is the human ortholog of the mitochondrial E. coli $23 \mathrm{~S}$ rRNA 2'-O-methyltransferase (yeast's Mrm2) [52,142]. FTSJ2 has been implicated in cell proliferation and seen to be overexpressed in different cancer cell lines, especially in lung carcinoma cells [53]. Moreover, a later study found an amplification of the FTSJ2 genomic locus, as well as an increase in FTSJ2 mRNA levels in non-small cell lung cancer (NSCLC). Thus, FTSJ2 has been identified as a new lung cancer oncogene candidate, even if its role in the disease in not completely clear today [143]. Surprisingly, another study compared two lung adenocarcinoma cell sublines and demonstrated that FTSJ2 mRNA levels were lower in the more invasive one. In addition, an overexpression of FTSJ2 in the highly aggressive rhabdomyosarcoma cells (TE671) turned out to inhibit their invasion and migration capabilities [142]. This seems to contradict what was just stated, but it is speculated that FTSJ2 is advantageous for cancer cells only when they are in a less aggressive stage. FTSJ2 expression may provide a transient advantage for the tumor, and once a certain threshold in the malignancy development is exceeded, FTSJ2 may become a drawback and cancer cells try to eliminate it.

\section{Nm in mRNAs}

mRNAs can be co- or post-transcriptionally modified, which impacts their fine steady state level. When it comes to Nm modification, it has been mostly observed in the mRNA cap, but recently also internally in the coding DNA sequence (CDS). Indirect effects on mRNA expression can be observed when a lack of Nm affects the small nuclear RNA (snRNA)-regulated mRNA splicing.

\section{1. $m R N A$ s and Cap Protection}

The cap structure is added to the $5^{\prime}$ - end of eukaryotic and some viral mRNAs during transcription and is essential for mRNA stability, pre-mRNA processing, nuclear export, and cap-dependent protein synthesis [144-149]. The so-called "cap 0" $\left(\mathrm{m} 7 \mathrm{G}\left(5^{\prime}\right) \mathrm{ppp}\left(5^{\prime}\right) \mathrm{N}\right)$ consists of a 7-methylguanosine addition to the first transcribed nucleotide (N1) [150]. Further 2'-O-methylation can be added on the N1 and often also on the N2 (second transcribed nucleotide); here we are talking about "cap 1" (m7GpppNmN-) and "cap 2" (m7GpppNmNm-), respectively (Figure 3). CMTR1 2'-O-methylates the N1 [151] and CMTR2 2'-O-methylates the N2 [152,153]. In general, higher eukaryotes have a "cap2" while lower eukaryotes have "cap 1" [12,154,155].

\subsection{CMTR1 and Diseases}

CMTR1 (ISG95, FTSJD2, KIAA0082) is the human 2'-O-methyltrasferase that modifies the N1 (first transcribed nucleotide) of the mRNA cap ([151] and Figure 3). Deregulation in CMTR1 expression have been linked to different disease conditions, mostly through mechanisms related to distinguishing self from non-self RNA [156]. This is expected as the Nm-modified N1 of the cap serves as part of the innate host defense mechanism. In contrast, uncapped RNAs, including viral transcripts, trigger an interferon-mediated antiviral response [157-161].

\subsection{CMTR1 and Asthma}

Inhaled corticosteroids (ICS) are the most effective controller medications for asthma, but some patients experience severe asthma exacerbations despite ICS treatment [162]. This variability in ICS response is due to genetic variations and the rs2395672 SNP in CMTR1 has been associated with increased risk of exacerbations. Moreover, CMTR1 mRNA was overexpressed in nasal lavage samples 
from patients experiencing exacerbations in an independent microarray data set. These studies implicate CMTR1, an mRNA Nm methyltransferase, as a novel candidate gene with potential roles in the pathogenesis of asthma exacerbations [156]. The exact role of CMTR1 in asthma is not clear but could be related to the fact that the transcription of human CMTR1 is interferon-stimulated and CMTR1 participates in cellular defense mechanisms against viral infection $[163,164]$. It should be noted that respiratory viruses are major triggers of exacerbations and a major cause of morbidity and mortality in adults and children with asthma $[156,165]$. Thus, by regulating mRNA stability and transcriptional expression of interferon-induced genes, CMTR1 may play an important role in regulating genes involved in immune responses to viral infections.

\subsection{CMTR1 and Alzheimer's Disease}

Alzheimer's disease (AD) is the most common form of dementia [166], characterized by the formation of amyloid plaques (A $\beta$ ). Chronic activation of microglial cells creates a pro-inflammatory environment, which is believed to be central for the development of the disease as well as its progression [167]. There is an upregulation of immune system-related pathways such as interferon-gamma signaling pathways at 10 weeks old (versus 6 weeks old) in the brain of AD mice model (5xFAD mice). Interestingly, in those mice, CMTR1 was found among the 20 most upregulated proteins [168]. Again, we can imagine that CMTR1 supports the expression of genes associated with this innate immune response, and thus contributes to the development of AD.

\section{RNA cap structure}

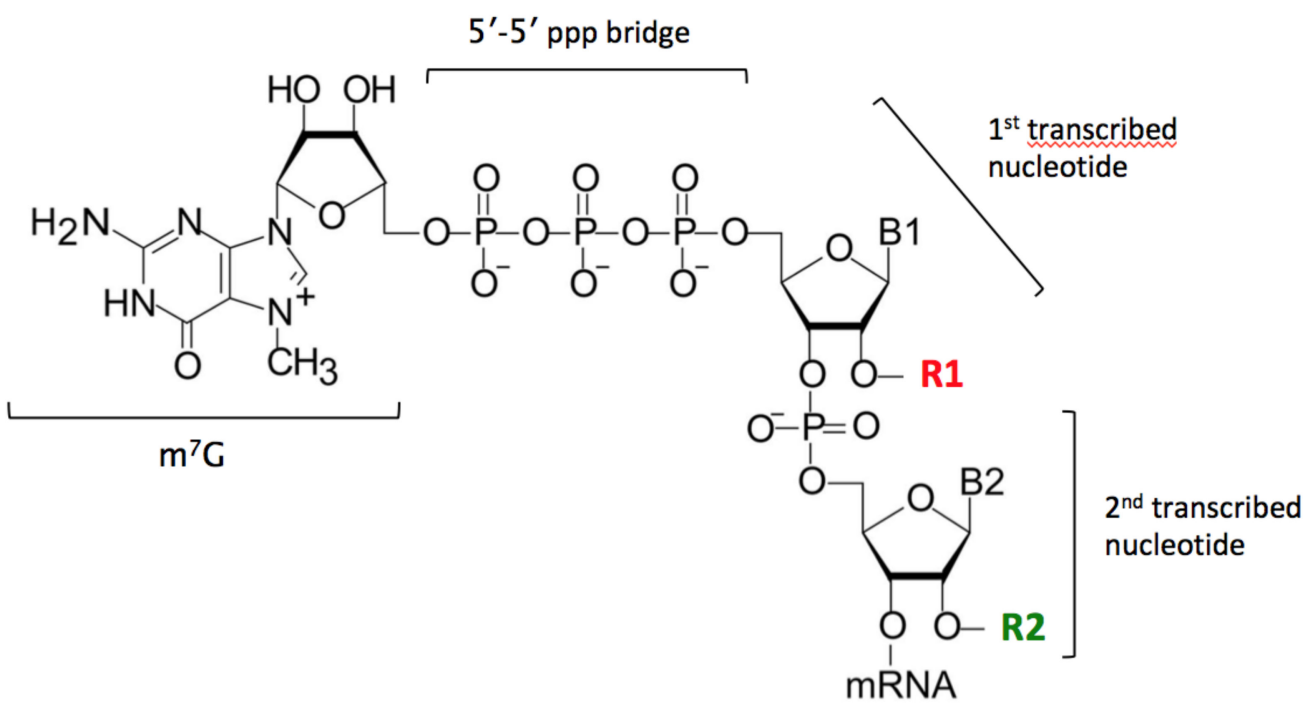

\begin{tabular}{|lll|}
\hline Cap0 & Cap1 & Cap2 \\
\hline R1 = H & R1 $=\mathrm{CH}_{3}$ & R1 $=\mathrm{CH}_{3}$ \\
R2 = H & R2 $=\mathrm{H}$ & R2 $=\mathrm{CH}_{3}$ \\
\hline
\end{tabular}

Figure 3. RNA cap structure: The cap0 structure consists of a guanosine residue, methylated in the N-7 position, which is bound to the terminal $5^{\prime}$-end nucleotide of the mRNA with a $5^{\prime}-5^{\prime}$ triphosphate bridge. Subsequent $2^{\prime}$-O-methylation in the ribose of the first, or both the first and the second, transcribed mRNA nucleotides leads to the formation of cap1 or cap2, respectively. This figure has been adapted from Reference [151]. 


\subsection{CMTR1 and Cancer}

CMTR1 has not been directly linked to cancer, but multiple studies suggest a possible role in tumors. Microorganisms' DNA/RNA signatures and integration sites in the host genome are promising biomarkers for human oral cavity and oropharyngeal squamous cell carcinomas (OCSCC/OPSCC) diagnosis and prognosis. Genomic elements of the oncogenic John Cunningham (JC) polyomavirus are found in the chromosomes of OCSCC cells and among the concerned integration sites are intronic regions of CMTR [169]. It is possible that these insertions alter CMTR gene expression in a way that promotes oncogenesis. It would be interesting to deepen that study by applying the RiboMethSeq approach or others Nm detection methods to highlight any potential loss of CMTR-dependent Nm modifications in the concerned cancer tissues.

Mutations in Janus kinase 3 (JAK3) occur frequently in T-cell acute lymphoblastic leukemia (T-ALL) and are able to drive cellular transformation and the development of T-ALL in mouse models [170]. JAK3 is a tyrosine kinase that can control protein activity and is an attractive therapeutic target to help establish a more patient-specific therapy [171]. Curiously, CMTR1 phosphorylation is significantly increased upon inhibition of JAK3 activity [172]. Thus, CMTR1 activity seems to be affected in a cancer-associated mutant context and may be one of the downstream explanations for the JAK3 mutant cancer phenotype.

Finally, NSCLC (non-small cell lung cancer, already mentioned in the FTSJ2 section) accounts for approximately $80-85 \%$ of lung cancers and is a leading cause of cancer-related mortality in both men and women worldwide $[173,174]$. ALK gene rearrangements, producing fusion oncogenes, is a driving mutation underlying the development of NSCLC [175]. The EML4-ALK oncogene is already well described [176,177], but $A L K$ can also form rearrangements with CMTR1. It is yet to be confirmed if the CMTR1-ALK fusion gene is also oncogenic and if it has a role in cancer drug resistance [178].

\section{6. $m R N A$ and Splicing}

The removal of introns from the precursor mRNA (pre-mRNA), or the so-called splicing, is an essential step in the production and diversity of functional mRNAs transcripts. The process is ensured by the spliceosome machinery that contains small nuclear ribonucleoprotein (snRNP) units (reviewed in Reference [179]).

\section{7. snRNAs}

The RNA components of the spliceosome are the small nuclear RNAs (snRNAs), most of which possess multiple modified nucleotides, including $\mathrm{Nm}$ and pseudouridine $(\psi)$ positions that support the strong secondary structure and protein-binding capacity of snRNAs. Many of those modifications are essential for spliceosome assembly or efficiency (reviewed in References $[180,181]$. For example, the $5^{\prime}$ - end of U2 snRNA contains four specific 2'-O-methylated bases and each of them is required for splicing [182]. Importantly, U2 snRNA seems to play a role in alternative splicing in the brain as disruption of one of the U2 copies causes cerebellar ataxia and neurodegeneration in mice [183]. It would be interesting to know if the loss of individual modifications on snRNAs can be responsible for any disease conditions.

\section{8. scaRNAs}

The majority of modifications on snRNAs are applied in the Cajal bodies with the help of small Cajal body specific RNAs (scaRNAs) [184-186]. ScaRNAs are structurally and functionally indistinguishable from snoRNAs and can even interact with common enzymes like fibrillarin and dyskerin to guide the modifications on their target RNAs $[187,188]$. Their classification can be challenging but the conventional view is that they differ in their localization and type of targeted RNAs [189]. The role of scaRNAs in the maturation of spliceosomal snRNAs and the fact that 
alternative splicing is particularly prevalent in the brain suggest that neurons could be among the cell types most sensitive to disruption of scaRNA activity [190].

Alternative splicing also plays an important role in regulating mammalian heart development. The decreased expression of 12 scaRNAs was reported in congenitally abnormal human hearts with subsequent dysregulated alternative splicing of several genes associated with heart development [191]. Nine of the scaRNAs carry a C/D box and are predicted to participate in Nm modification of $\mathrm{U} 2$ and U6 snRNAs [191]. The phenotype seems to be conserved among vertebrates as a knock-down of the $\mathrm{C} / \mathrm{D}$ box containing SNORD94 produces developmental abnormalities, including heart malformations, which is also found in zebrafish [192].

\section{9. $m R N A$ s and Internal Nm Modifications}

Modification studies on mRNAs have been mostly limited to the abundant and easily detectable $\mathrm{m}^{6} \mathrm{~A}$ modification until the discovery that tRNA modifying enzymes like pseudouridine synthases (Pus) can also target mRNAs [193-195].

When it comes to Nm modifications, the tRNA 2'-O-methyltransferase, TRM44 (mentioned in previous chapter 2.4) was found to associate with polyadenylated (poly(A)) RNA in yeast, suggesting it may also target mRNAs in addition to tRNAs [196]. It is actually not uncommon for RNA-modifying enzymes to have multiple RNA targets [43] and even C/D box snoRNAs, typically reserved for rRNA $\mathrm{Nm}$ modification, that can target tRNAs in Archaea [197]. Interestingly, this capacity of a C/D box RNA to target tRNA instead of rRNA seems to be conserved in human (Vitali and Kiss, personal communication).

In yeast, Spb1, the rRNA 2'-O-methyltransferase (mentioned in a previous chapter), was found not only to associate with mRNAs, but also to methylate specific positions, methylations that seem to maintain their steady state level [198]. The human ortholog FTSJ3 has also been found in the poly(A) mRNP (messenger ribonucleoprotein) interactomes in multiple human cell lines [196,199,200], and its capacity to Nm-modify mRNAs awaits confirmation [55]. However, very recently, FTSJ3 was shown to methylate viral HIV-1 RNA [201]. This Nm deposition by FTSJ3 on HIV-1 RNA seems crucial for the virus to evade innate immune recognition. Although a recent discovery, mRNA internal (outside the cap) Nm modifications are officially a fact in mammalian mRNAs. They are mostly found in CDS, and especially near splice sites, but also in $5^{\prime}$ and $3^{\prime}$ UTR (untranslated regions), as well as in introns (suggesting that $\mathrm{Nm}$ is installed co-transcriptionally in the nucleus), and a small fraction in alternatively spliced regions [4]. Moreover, Nm within coding regions of mRNA disrupts key steps in codon reading during translation. More specifically, Nm on mRNA CDS leads to excessive rejection of cognate aminoacylated-tRNAs, probably due to sterical perturbation of the ribosomal-monitoring bases with cognate codon-anticodon helices interactions [202].

As it took time to find Nm modifications in mRNAs due to the low abundance of mRNAs compared to other classes of RNA, related diseases have not been described yet. Still, as more and more tRNA and rRNA 2'-O-methyltransferases seem to also target mRNAs [198], the diseases associated to these enzymes may also be due to the effects on their mRNA targets.

\section{Nm in Small RNAs Silencing Pathways}

The small non-coding RNA (sncRNA) silencing pathways regulate gene expression transcriptionally or post-transcriptionally. There are three main classes of sncRNAs: mi- (micro), si- (small-interfering), and piRNAs (PIWI-interacting RNAs). Each of them partners with an endonuclease from the argonaute (Ago) family and guides through sequence complementarity the silencing of a target mRNA [203,204]. In order to escape poly-uridilation and subsequent exonuclease degradation, miRNAs and siRNAs in plants, and siRNAs and piRNAs in animals need to receive a 2'-O-methylation on their $3^{\prime}$-end. 


\section{HENMT1}

The Nm modification at the $3^{\prime}$ - end of the concerned small RNAs is catalyzed by HENMT1 (HUA enhancer 1, also known as pimet for piRNA methylase in animals), and is particularly important for the PIWI/piRNA pathway that protects gonadal cells from transposable elements (TE) insertional mutagenesis in animals [6,10,205-211]. A recent paper investigating a Henmt1 mouse mutant demonstrated that HENMT1 methyltransferase is essential for mouse spermatogenesis [212]. Lack of HENMT1 and the associated reduction in methylation of the piRNA $3^{\prime}$ - end led to piRNA instability and de-repression of TE in germ cells results in malformed spermatids and male infertility [212]. Consistent with HENMT1 having an important role in the human testis, mRNA HENMT1 is expressed in all germ cell types and HENMT1 proteins localized in the cytoplasm of all stages of germ cells (spermatogonia, spermatocytes, and spermatids), as well as Sertoli cells, with highest levels in spermatocytes [213]. Moreover, a pathological fusion transcript between regulator of chromosome condensation 1 (RCC1) and HENMT1 was identified in testicular germ cell tumors [214].

However, the ancestral role of the piRNA pathway does not seem to have been restricted only to the germline [215-217]. Small amounts of piRNAs have been found in epithelial cells in Hydra (Cnidaria phylum) [218] and seem to be common among the somatic lineage of the Arthropod phylum [219]. In Aplysia (Mollusca phylum), piRNAs were described in the central nervous system where they seem to play a role [220]. HENMT1 Nm methyltransferase being essential for piRNA stability in germ cells is also implicated in the somatic-piRNA related biological processes in Drosophila melanogaster. There is also evidence for somatic role of HENMT1 related to Ago2-loaded small RNAs, its other RNA targets in D. melanogaster. Indeed, fly mutants for HEN1 (pimet) show an accelerated neurodegeneration (brain vacuolization) and memory default [221], which are phenotypes common for Ago2 mutants [221,222].

\section{Conclusions}

This review aimed to synthesize most of the Nm related human diseases known to date in a systematic manner. However, the structuring task was hampered as, often, the same enzymes can modify different classes of RNAs, like SPB1 that acts both on mRNA and rRNA for example. Also, sometimes, small guide RNAs need to Nm-modify other small guide RNAs that will only then regulate gene expression, like in the case of scaRNAs and snRNAs. One could justifiably feel jealous of the multitasking capabilities that Nm enzymes and guides can have and of the interesting interplay as well as the extraordinary conservation (enzyme and targets) that exists between them.

In conclusion, Nm modification is a potent source for better disease understanding that has been shadowed for a long time by the difficulties in detecting it. With the latest technical advances toward $\mathrm{Nm}$ detection, we are awaiting more insights in the biological roles of the still mysterious and ancient 2'-O-methylation RNA modification. Finally, we want here to sincerely acknowledge all pioneers on RNA modifications discovery (mostly rRNA and tRNA at the time) that paved the road brick by brick for us in this re-emerging field of RNA modifications.

Author Contributions: D.G.D and C.C. conceived the structure of the manuscript. D.G.D., L.T., and C.C. wrote the manuscript together. D.G.D. designed the figures and tables.

Funding: This work received financial support from the European COST action EPITRAN CA16120 (European Epitranscriptomics Network) and from the Action Incitative IBPS 2018, the Fondation Maladies Rares (FMR)-Genomics\#1 2018, the CNRS and Sorbonne Universite to C.C. and LT. D.G.D. has a PhD fellowship of the doctoral school Complexité du Vivant (ED515) from the French Ministère de la Recherche et de l'Enseignement Supérieur.

Acknowledgments: We thank Amélie Piton and Elise Schaefer from the Hôpitaux Universitaire de Strasbourg for sharing unpublished data and personal communication. We thank Patrice Vitali and Tamas Kiss from the Laboratoire de Biologie Moléculaire Eucaryote of Toulouse for sharing unpublished data and personal communication. We thank Yuri Motorin, Virginie Marchand, Jean-Yves Roignant, Damien Bregeon, Catherine Goyenvalle, and Jozef Gecz for helpful discussions on Nm modification and ongoing collaborations. We also thank all the members of the Transgenerational Epigenetics \& Small RNA Biology (TErBIO) laboratory for helpful 
discussions. C.C. is a member of the COST action EPITRAN. D.G.D. thanks the Réseau André Picard for its support on travel fellowship grants and the COST action "EPITRAN" CA16120 for attending the first Training School on Epitranscriptomics in Nancy 2018.

Conflicts of Interest: The authors declare no conflict of interest.

\section{References}

1. Darzacq, X.; Jády, B.E.; Verheggen, C.; Kiss, A.M.; Bertrand, E.; Kiss, T. Cajal body-specific small nuclear RNAs: A novel class of 2'-O-methylation and pseudouridylation guide RNAs. EMBO J. 2002, 21, 2746-2756. [CrossRef] [PubMed]

2. Rebane, A.; Roomere, H.; Metspalu, A. Locations of several novel 2'-O-methylated nucleotides in human $28 \mathrm{~S}$ rRNA. BMC Mol. Biol. 2002, 3, 1. [CrossRef]

3. Somme, J.; Van Laer, B.; Roovers, M.; Steyaert, J.; Versées, W.; Droogmans, L. Characterization of two homologous 2'-O-methyltransferases showing different specificities for their tRNA substrates. RNA 2014, 20, 1257-1271. [CrossRef] [PubMed]

4. Dai, Q.; Moshitch-Moshkovitz, S.; Han, D.; Kol, N.; Amariglio, N.; Rechavi, G.; Dominissini, D.; He, C. Nm-seq maps 2'-O-methylation sites in human mRNA with base precision. Nat. Methods 2017, 14, 695-698. [CrossRef] [PubMed]

5. Li, J.; Yang, Z.; Yu, B.; Liu, J.; Chen, X. Methylation Protects miRNAs and siRNAs from a 3'-End Uridylation Activity in Arabidopsis. Curr. Biol. 2005, 15, 1501-1507. [CrossRef] [PubMed]

6. Yu, B.; Yang, Z.; Li, J.; Minakhina, S.; Yang, M.; Padgett, R.W.; Steward, R.; Chen, X. Methylation as a crucial step in plant microRNA biogenesis. Science 2005, 307, 932-935. [CrossRef] [PubMed]

7. Kurth, H.M.; Mochizuki, K. 2'-O-methylation stabilizes Piwi-associated small RNAs and ensures DNA elimination in Tetrahymena. RNA 2009, 15, 675-685. [CrossRef]

8. Zhao, Y.; Mo, B.; Chen, X. Mechanisms that impact microRNA stability in plants. RNA Biol. 2012, 9, $1218-1223$. [CrossRef]

9. Horwich, M.D.; Li, C.; Matranga, C.; Vagin, V.; Farley, G.; Wang, P.; Zamore, P.D. The Drosophila RNA methyltransferase, DmHen1, modifies germline piRNAs and single-stranded siRNAs in RISC. Curr. Biol. 2007, 17, 1265-1272. [CrossRef]

10. Saito, K.; Sakaguchi, Y.; Suzuki, T.; Suzuki, T.; Siomi, H.; Siomi, M.C. Pimet, the Drosophila homolog of HEN1, mediates 2'-O-methylation of Piwi- interacting RNAs at their 3' ends. Genes Dev. 2007, 21, 1603-1608. [CrossRef]

11. Sproat, B.S.; Lamond, A.I.; Beijer, B.; Neuner, P.; Ryder, U. Highly efficient chemical synthesis of 2'-O-methyloligoribonucleotides and tetrabiotinylated derivatives; novel probes that are resistant to degradation by RNA or DNA specific nucleases. Nucleic Acids Res. 1989, 17, 3373-3386. [CrossRef] [PubMed]

12. Byszewska, M.; Śmietański, M.; Purta, E.; Bujnicki, J.M. RNA methyltransferases involved in $5^{\prime}$ cap biosynthesis. RNA Biol. 2014, 11, 1597-1607. [CrossRef]

13. Kumar, S.; Mapa, K.; Maiti, S. Understanding the effect of locked nucleic acid and 2'-O-methyl modification on the hybridization thermodynamics of a miRNA-mRNA pair in the presence and absence of AfPiwi protein. Biochemistry 2014, 53, 1607-1615. [CrossRef]

14. Yildirim, I.; Kierzek, E.; Kierzek, R.; Schatz, G.C. Interplay of LNA and 2'-O-methyl RNA in the structure and thermodynamics of RNA hybrid systems: A molecular dynamics study using the revised AMBER force field and comparison with experimental results. J. Phys. Chem. B 2014, 118, 14177-14187. [CrossRef] [PubMed]

15. Inoue, H.; Hayase, Y.; Imura, A.; Iwai, S.; Miura, K.; Ohtsuka, E. Synthesis and hybridization studies on two complementary nona (2'-O-methyl) ribonucleotides. Nucleic Acids Res. 1987, 15, 6131-6148. [CrossRef] [PubMed]

16. Kawai, G.; Yamamoto, Y.; Kamimura, T.; Masegi, T.; Sekine, M.; Hata, T.; Iimori, T.; Watanabe, T.; Miyazawa, T.; Yokoyama, S. Conformational rigidity of specific pyrimidine residues in tRNA arises from posttranscriptional modifications that enhance steric interaction between the base and the 2 '-hydroxyl group. Biochemistry 1992, 31, 1040-1046. [CrossRef] [PubMed]

17. Majlessi, M.; Nelson, N.C.; Becker, M.M. Advantages of 2'-O-methyl oligoribonucleotide probes for detecting RNA targets. Nucleic Acids Res. 1998, 26, 2224-2229. [CrossRef] 
18. Tsourkas, A.; Behlke, M.A.; Bao, G. Hybridization of 2'-O-methyl and 2'-deoxy molecular beacons to RNA and DNA targets. Nucleic Acids Res. 2002, 30, 5168-5174. [CrossRef]

19. Lebars, I.; Legrand, P.; Aimé, A.; Pinaud, N.; Fribourg, S.; Di Primo, C. Exploring TAR-RNA aptamer loop-loop interaction by X-ray crystallography, UV spectroscopy and surface plasmon resonance. Nucleic Acids Res. 2008, 36, 7146-7156. [CrossRef]

20. Hou, Y.-M.; Zhang, X.; Holland, J.A.; Davis, D.R. An important 2'-OH group for an RNA-protein interaction. Nucleic Acids Res. 2001, 29, 976-985. [CrossRef]

21. Lacoux, C.; Di Marino, D.; Pilo Boyl, P.; Zalfa, F.; Yan, B.; Ciotti, M.T.; Falconi, M.; Urlaub, H.; Achsel, T.; Mougin, A.; et al. BC1-FMRP interaction is modulated by 2'-O-methylation: RNA-binding activity of the tudor domain and translational regulation at synapses. Nucleic Acids Res. 2012, 40, 4086-4096. [CrossRef] [PubMed]

22. Jones, S.; Daley, D.T.A.; Luscombe, N.M.; Berman, H.M.; Thornton, J.M. Protein-RNA interactions: A structural analysis. Nucleic Acids Res. 2001, 29, 943-954. [CrossRef]

23. Treger, M.; Westhof, E. Statistical analysis of atomic contacts at RNA-protein interfaces. J. Mol. Recognit. 2001, 14, 199-214. [CrossRef] [PubMed]

24. Douthwaite, S.; Kirpekar, F. Identifying modifications in RNA by MALDI mass spectrometry. Methods Enzymol. 2007, 425, 3-20.

25. Grosjean, H.; Keith, G.; Droogmans, L. Detection and quantification of modified nucleotides in RNA using thin-layer chromatography. Methods Mol. Biol. 2004, 265, 357-391. [PubMed]

26. Grosjean, H.; Droogmans, L.; Roovers, M.; Keith, G. Detection of enzymatic activity of transfer RNA modification enzymes using radiolabeled tRNA substrates. Methods Enzymol. 2007, 425, 55-101. [PubMed]

27. Maden, B.E. Mapping 2'-O-methyl groups in ribosomal RNA. Methods 2001, 25, 374-382. [CrossRef]

28. Deryusheva, S.; Gall, J.G.; Matera, A.G. Small Cajal Body-specific RNAs of Drosophila Function in the Absence of Cajal Bodies. MBoC 2009, 20, 5250-5259. [CrossRef]

29. Belin, S.; Beghin, A.; Solano-Gonzàlez, E.; Bezin, L.; Brunet-Manquat, S.; Textoris, J.; Prats, A.-C.; Mertani, H.C.; Dumontet, C.; Diaz, J.-J. Dysregulation of ribosome biogenesis and translational capacity is associated with tumor progression of human breast cancer cells. PLoS ONE 2009, 4, e7147. [CrossRef]

30. Yu, Y.T.; Shu, M.D.; Steitz, J.A. A new method for detecting sites of 2'-O-methylation in RNA molecules. RNA 1997, 3, 324-331.

31. Saikia, M.; Dai, Q.; Decatur, W.A.; Fournier, M.J.; Piccirilli, J.A.; Pan, T. A systematic, ligation-based approach to study RNA modifications. RNA 2006, 12, 2025-2033. [CrossRef] [PubMed]

32. Buchhaupt, M.; Peifer, C.; Entian, K.-D. Analysis of 2'-O-methylated nucleosides and pseudouridines in ribosomal RNAs using DNAzymes. Anal. Biochem. 2007, 361, 102-108. [CrossRef] [PubMed]

33. Dong, Z.-W.; Shao, P.; Diao, L.-T.; Zhou, H.; Yu, C.-H.; Qu, L.-H. RTL-P: A sensitive approach for detecting sites of 2'-O-methylation in RNA molecules. Nucleic Acids Res. 2012, 40, e157. [CrossRef]

34. Marchand, V.; Blanloeil-Oillo, F.; Helm, M.; Motorin, Y. Illumina-based RiboMethSeq approach for mapping of 2'-O-Me residues in RNA. Nucleic Acids Res. 2016, 44, e135. [CrossRef]

35. Marchand, V.; Ayadi, L.; El Hajj, A.; Blanloeil-Oillo, F.; Helm, M.; Motorin, Y. High-Throughput Mapping of 2'-O-Me Residues in RNA Using Next-Generation Sequencing (Illumina RiboMethSeq Protocol). In RNA Methylation: Methods and Protocols; Lusser, A., Ed.; Springer New York: New York, NY, USA, 2017; pp. 171-187. ISBN 9781493968077.

36. Marchand, V.; Pichot, F.; Thüring, K.; Ayadi, L.; Freund, I.; Dalpke, A.; Helm, M.; Motorin, Y. Next-Generation Sequencing-Based RiboMethSeq Protocol for Analysis of tRNA 2'-O-Methylation. Biomolecules 2017, 7, 13. [CrossRef] [PubMed]

37. Ayadi, L.; Motorin, Y.; Marchand, V. Quantification of 2'-O-Me Residues in RNA Using Next-Generation Sequencing (Illumina RiboMethSeq Protocol). In RNA Detection: Methods and Protocols; Gaspar, I., Ed.; Springer New York: New York, NY, USA, 2018; ISBN 9781493972135.

38. Wang, N.; Qu, S.; Sun, W.; Zeng, Z.; Liang, H.; Zhang, C.-Y.; Chen, X.; Zen, K. Direct quantification of $3^{\prime}$ terminal 2'-O-methylation of small RNAs by RT-qPCR. RNA 2018, 24, 1520-1529. [CrossRef]

39. Zhu, Y.; Pirnie, S.P.; Carmichael, G.G. High-throughput and site-specific identification of 2'-O-methylation sites using ribose oxidation sequencing (RibOxi-seq). RNA 2017, 23, 1303-1314. [CrossRef]

40. Motorin, Y.; Marchand, V. Detection and Analysis of RNA Ribose 2'-O-Methylations: Challenges and Solutions. Genes 2018, 9, 642. [CrossRef] 
41. Towns, W.L.; Begley, T.J. Transfer RNA methytransferases and their corresponding modifications in budding yeast and humans: Activities, predications, and potential roles in human health. DNA Cell Biol. 2012, 31, 434-454. [CrossRef]

42. Torres, A.G.; Batlle, E.; Ribas de Pouplana, L. Role of tRNA modifications in human diseases. Trends Mol. Med. 2014, 20, 306-314. [CrossRef]

43. Chou, H.-J.; Donnard, E.; Gustafsson, H.T.; Garber, M.; Rando, O.J. Transcriptome-wide Analysis of Roles for tRNA Modifications in Translational Regulation. Mol. Cell 2017, 68, 978-992. [CrossRef] [PubMed]

44. Ashraf, S.S.; Guenther, R.H.; Ansari, G.; Malkiewicz, A.; Sochacka, E.; Agris, P.F. Role of modified nucleosides of yeast tRNA(Phe) in ribosomal binding. Cell Biochem. Biophys. 2000, 33, 241-252. [CrossRef]

45. Pintard, L.; Lecointe, F.; Bujnicki, J.M.; Bonnerot, C.; Grosjean, H.; Lapeyre, B. Trm7p catalyses the formation of two 2'-O-methylriboses in yeast tRNA anticodon loop. EMBO J. 2002, 21, 1811-1820. [CrossRef] [PubMed]

46. Benítez-Páez, A.; Villarroya, M.; Douthwaite, S.; Gabaldón, T.; Armengod, M.-E. YibK is the 2'-O-methyltransferase TrmL that modifies the wobble nucleotide in Escherichia coli tRNA(Leu) isoacceptors. RNA 2010, 16, 2131-2143. [CrossRef]

47. Bügl, H.; Fauman, E.B.; Staker, B.L.; Zheng, F.; Kushner, S.R.; Saper, M.A.; Bardwell, J.C.; Jakob, U. RNA methylation under heat shock control. Mol. Cell 2000, 6, 349-360. [CrossRef]

48. Feder, M.; Pas, J.; Wyrwicz, L.S.; Bujnicki, J.M. Molecular phylogenetics of the RrmJ/fibrillarin superfamily of ribose 2'-O-methyltransferases. Gene 2003, 302, 129-138. [CrossRef]

49. Guy, M.P.; Phizicky, E.M. Conservation of an intricate circuit for crucial modifications of the tRNAPhe anticodon loop in eukaryotes. RNA 2015, 21, 61-74. [CrossRef]

50. Guy, M.P.; Podyma, B.M.; Preston, M.A.; Shaheen, H.H.; Krivos, K.L.; Limbach, P.A.; Hopper, A.K.; Phizicky, E.M. Yeast Trm7 interacts with distinct proteins for critical modifications of the tRNAPhe anticodon loop. RNA 2012, 18, 1921-1933. [CrossRef]

51. Noma, A.; Kirino, Y.; Ikeuchi, Y.; Suzuki, T. Biosynthesis of wybutosine, a hyper-modified nucleoside in eukaryotic phenylalanine tRNA. EMBO J. 2006, 25, 2142-2154. [CrossRef]

52. Pintard, L.; Bujnicki, J.M.; Lapeyre, B.; Bonnerot, C. MRM2 encodes a novel yeast mitochondrial 21S rRNA methyltransferase. EMBO J. 2002, 21, 1139-1147. [CrossRef]

53. Ching, Y.-P.; Zhou, H.-J.; Yuan, J.-G.; Qiang, B.-Q.; Kung Hf, H.-F.; Jin, D.-Y. Identification and characterization of FTSJ2, a novel human nucleolar protein homologous to bacterial ribosomal RNA methyltransferase. Genomics 2002, 79, 2-6. [CrossRef] [PubMed]

54. Pintard, L.; Kressler, D.; Lapeyre, B. Spb1p Is a Yeast Nucleolar Protein Associated with Nop1p and Nop58p That Is Able to BindS-Adenosyl-1-Methionine In Vitro. Mol. Cell. Biol. 2000, 20, 1370-1381. [CrossRef] [PubMed]

55. Simabuco, F.M.; Morello, L.G.; Aragão, A.Z.B.; Paes Leme, A.F.; Zanchin, N.I.T. Proteomic characterization of the human FTSJ3 preribosomal complexes. J. Proteome Res. 2012, 11, 3112-3126. [CrossRef] [PubMed]

56. Maulik, P.K.; Mascarenhas, M.N.; Mathers, C.D.; Dua, T.; Saxena, S. Prevalence of intellectual disability: A meta-analysis of population-based studies. Res. Dev. Disabil. 2011, 32, 419-436. [CrossRef] [PubMed]

57. Willems, P.; Vits, L.; Buntinx, I.; Raeymaekers, P.; Van Broeckhoven, C.; Ceulemans, B. Localization of a gene responsible for nonspecific mental retardation (MRX9) to the pericentromeric region of the X chromosome. Genomics 1993, 18, 290-294. [CrossRef]

58. Hamel, B.C.J.; Smits, A.P.T.; van den Helm, B.; Smeets, D.F.; Knoers, N.V.; van Roosmalen, T.; Thoonen, G.H.J.; Assman-Hulsmans, C.F.; Ropers, H.-H.; Mariman, E.C.M.; et al. Four families (MRX43, MRX44, MRX45, MRX52) with nonspecific X-linked mental retardation: Clinical and psychometric data and results of linkage analysis. Am. J. Med. Genet. 1999, 85, 290-304. [CrossRef]

59. Freude, K.; Hoffmann, K.; Jensen, L.-R.; Delatycki, M.B.; des Portes, V.; Moser, B.; Hamel, B.; van Bokhoven, H.; Moraine, C.; Fryns, J.-P.; et al. Mutations in the FTSJ1 Gene Coding for a Novel S-Adenosylmethionine-Binding Protein Cause Nonsyndromic X-Linked Mental Retardation. Am. J. Hum. Genet. 2004, 75, 305-309. [CrossRef]

60. Ramser, J.; Winnepenninckx, B.; Lenski, C.; Errijgers, V.; Platzer, M.; Schwartz, C.E.; Meindl, A.; Kooy, R.F. A splice site mutation in the methyltransferase gene FTSJ1 in Xp11.23 is associated with non-syndromic mental retardation in a large Belgian family (MRX9). J. Med. Genet. 2004, 41, 679-683. [CrossRef]

61. Froyen, G.; Bauters, M.; Boyle, J.; Van Esch, H.; Govaerts, K.; van Bokhoven, H.; Ropers, H.-H.; Moraine, C.; Chelly, J.; Fryns, J.-P.; et al. Loss of SLC38A5 and FTSJ1 at Xp11.23 in three brothers with non-syndromic 
mental retardation due to a microdeletion in an unstable genomic region. Hum. Genet. 2007, 121, 539-547. [CrossRef]

62. Dai, L.; Xing, L.; Gong, P.; Zhang, K.; Gao, X.; Zheng, Z.; Zhou, J.; Guo, Y.; Guo, S.; Zhang, F. Positive association of the FTSJ1 gene polymorphisms with nonsyndromic X-linked mental retardation in young Chinese male subjects. J. Hum. Genet. 2008, 53, 592-597. [CrossRef]

63. Takano, K.; Nakagawa, E.; Inoue, K.; Kamada, F.; Kure, S.; Goto, Y.-I.; Consortium, J.M.R. A loss-of-function mutation in the FTSJ1 gene causes nonsyndromic X-linked mental retardation in a japanese family. Am. J. Med. Genet. B Neuropsychiatr. Genet. 2008, 147, 479-484. [CrossRef]

64. Guy, M.P.; Shaw, M.; Weiner, C.L.; Hobson, L.; Stark, Z.; Rose, K.; Kalscheuer, V.M.; Gecz, J.; Phizicky, E.M. Defects in tRNA Anticodon Loop 2'-O-Methylation Are Implicated in Nonsyndromic X-Linked Intellectual Disability due to Mutations in FTSJ1. Hum. Mutat. 2015, 36, 1176-1187. [CrossRef] [PubMed]

65. Angelova, M.T.; Dimitrova, D.G.; Dinges, N.; Lence, T.; Worpenberg, L.; Carré, C.; Roignant, J.-Y. The Emerging Field of Epitranscriptomics in Neurodevelopmental and Neuronal Disorders. Front. Bioeng. Biotechnol. 2018, 6, 46. [CrossRef]

66. FTS1 Single Nucleotide Variant Reported by Ambry Genetics at Clinvar NCBI. Available online: https:/ /www.ncbi. nlm.nih.gov/clinvar/variation/208659/ (accessed on 27 July 2017).

67. Gong, P.; Li, J.; Dai, L.; Zhang, K.; Zheng, Z.; Gao, X.; Zhang, F. Genetic variations in FTSJ1 influence cognitive ability in young males in the Chinese Han population. J. Neurogenet. 2008, 22, 277-287. [CrossRef] [PubMed]

68. Chishty, M.; Reichel, A.; Abbott, N.J.; Begley, D.J. S-adenosylmethionine is substrate for carrier mediated transport at the blood-brain barrier in vitro. Brain Res. 2002, 942, 46-50. [CrossRef]

69. Han, L.; Guy, M.P.; Kon, Y.; Phizicky, E.M. Lack of 2'-O-methylation in the tRNA anticodon loop of two phylogenetically distant yeast species activates the general amino acid control pathway. PLoS Genet. 2018, 14, e1007288. [CrossRef] [PubMed]

70. Honda, S.; Hayashi, S.; Imoto, I.; Toyama, J.; Okazawa, H.; Nakagawa, E.; Goto, Y.-I.; Inazawa, J. Copy-number variations on the $\mathrm{X}$ chromosome in Japanese patients with mental retardation detected by array-based comparative genomic hybridization analysis. J. Hum. Genet. 2010, 55, 590-599. [CrossRef]

71. Giorda, R.; Bonaglia, M.C.; Beri, S.; Fichera, M.; Novara, F.; Magini, P.; Urquhart, J.; Sharkey, F.H.; Zucca, C.; Grasso, R.; et al. Complex Segmental Duplications Mediate a Recurrent dup $(X)(p 11.22-p 11.23)$ Associated with Mental Retardation, Speech Delay, and EEG Anomalies in Males and Females. Am. J. Hum. Genet. 2009, 85, 419. [CrossRef]

72. Leschziner, G.D.; Coffey, A.J.; Andrew, T.; Gregorio, S.P.; Dias-Neto, E.; Calafato, M.; Bentley, D.R.; Kinton, L.; Sander, J.W.; Johnson, M.R. Q8IYL2 is a candidate gene for the familial epilepsy syndrome of Partial Epilepsy with Pericentral Spikes (PEPS). Epilepsy Res. 2011, 96, 109-115. [CrossRef]

73. Polikanov, Y.S.; Melnikov, S.V.; Söll, D.; Steitz, T.A. Structural insights into the role of rRNA modifications in protein synthesis and ribosome assembly. Nat. Struct. Mol. Biol. 2015, 22, 342-344. [CrossRef]

74. Monaco, P.L.; Marcel, V.; Diaz, J.-J.; Catez, F. 2'-O-Methylation of Ribosomal RNA: Towards an Epitranscriptomic Control of Translation? Biomolecules 2018, 8, 106. [CrossRef]

75. Sloan, K.E.; Warda, A.S.; Sharma, S.; Entian, K.-D.; Lafontaine, D.L.J.; Bohnsack, M.T. Tuning the ribosome: The influence of rRNA modification on eukaryotic ribosome biogenesis and function. RNA Biol. 2017, 14, 1138-1152. [CrossRef] [PubMed]

76. Erales, J.; Marchand, V.; Panthu, B.; Gillot, S.; Belin, S.; Ghayad, S.E.; Garcia, M.; Laforêts, F.; Marcel, V.; Baudin-Baillieu, A.; et al. Evidence for rRNA 2'-O-methylation plasticity: Control of intrinsic translational capabilities of human ribosomes. Proc. Natl. Acad. Sci. USA 2017, 114, 12934-12939. [CrossRef]

77. Cavaillé, J.; Nicoloso, M.; Bachellerie, J.P. Targeted ribose methylation of RNA in vivo directed by tailored antisense RNA guides. Nature 1996, 383, 732-735. [CrossRef] [PubMed]

78. Bachellerie, J.P.; Cavaillé, J.; Hüttenhofer, A. The expanding snoRNA world. Biochimie 2002, 84, 775-790. [CrossRef]

79. Reichow, S.L.; Hamma, T.; Ferré-D’Amaré, A.R.; Varani, G. The structure and function of small nucleolar ribonucleoproteins. Nucleic Acids Res. 2007, 35, 1452-1464. [CrossRef] [PubMed]

80. Henras, A.K.; Soudet, J.; Gérus, M.; Lebaron, S.; Caizergues-Ferrer, M.; Mougin, A.; Henry, Y. The post-transcriptional steps of eukaryotic ribosome biogenesis. Cell. Mol. Life Sci. 2008, 65, 2334-2359. [CrossRef] 
81. Higa-Nakamine, S.; Suzuki, T.; Uechi, T.; Chakraborty, A.; Nakajima, Y.; Nakamura, M.; Hirano, N.; Suzuki, T.; Kenmochi, N. Loss of ribosomal RNA modification causes developmental defects in zebrafish. Nucleic Acids Res. 2012, 40, 391-398. [CrossRef]

82. Sridhar, P.; Gan, H.H.; Schlick, T. A computational screen for C/D box snoRNAs in the human genomic region associated with Prader-Willi and Angelman syndromes. J. Biomed. Sci. 2008, 15, 697-705. [CrossRef]

83. Doe, C.M.; Relkovic, D.; Garfield, A.S.; Dalley, J.W.; Theobald, D.E.H.; Humby, T.; Wilkinson, L.S.; Isles, A.R. Loss of the imprinted snoRNA mbii-52 leads to increased 5 htr2c pre-RNA editing and altered 5HT2CR-mediated behaviour. Hum. Mol. Genet. 2009, 18, 2140-2148. [CrossRef]

84. Cavaillé, J. Box C/D small nucleolar RNA genes and the Prader-Willi syndrome: A complex interplay. Wiley Interdiscip. Rev. RNA 2017, 8, e1417. [CrossRef] [PubMed]

85. Peters, J. Prader-Willi and snoRNAs. Nat. Genet. 2008, 40, 688-689. [CrossRef] [PubMed]

86. Belmonte, M.K.; Cook, E.H., Jr; Anderson, G.M.; Rubenstein, J.L.R.; Greenough, W.T.; Beckel-Mitchener, A.; Courchesne, E.; Boulanger, L.M.; Powell, S.B.; Levitt, P.R.; et al. Autism as a disorder of neural information processing: Directions for research and targets for therapy. Mol. Psychiatry 2004, 9, 646. [CrossRef] [PubMed]

87. Bolton, P.F.; Veltman, M.W.M.; Weisblatt, E.; Holmes, J.R.; Thomas, N.S.; Youings, S.A.; Thompson, R.J.; Roberts, S.E.; Dennis, N.R.; Browne, C.E.; et al. Chromosome 15q11-13 abnormalities and other medical conditions in individuals with autism spectrum disorders. Psychiatr. Genet. 2004, 14, 131-137. [CrossRef]

88. Cook, E.H., Jr; Scherer, S.W. Copy-number variations associated with neuropsychiatric conditions. Nature 2008, 455, 919-923. [CrossRef] [PubMed]

89. Cavaillé, J.; Buiting, K.; Kiefmann, M.; Lalande, M.; Brannan, C.I.; Horsthemke, B.; Bachellerie, J.-P.; Brosius, J.; Hüttenhofer, A. Identification of brain-specific and imprinted small nucleolar RNA genes exhibiting an unusual genomic organization. Proc. Natl. Acad. Sci. USA 2000, 97, 14311-14316. [CrossRef] [PubMed]

90. Bortolin-Cavaillé, M.-L.; Cavaillé, J. The SNORD115 (H/MBII-52) and SNORD116 (H/MBII-85) gene clusters at the imprinted Prader-Willi locus generate canonical box C/D snoRNAs. Nucleic Acids Res. 2012, 40, 6800-6807. [CrossRef]

91. Vitali, P.; Basyuk, E.; Le Meur, E.; Bertrand, E.; Muscatelli, F.; Cavaillé, J.; Huttenhofer, A. ADAR2-mediated editing of RNA substrates in the nucleolus is inhibited by C/D small nucleolar RNAs. J. Cell Biol. 2005, 169, 745-753. [CrossRef]

92. Kishore, S.; Stamm, S. The snoRNA HBII-52 regulates alternative splicing of the serotonin receptor $2 \mathrm{C}$. Science 2006, 311, 230-232. [CrossRef]

93. Sahoo, T.; del Gaudio, D.; German, J.R.; Shinawi, M.; Peters, S.U.; Person, R.E.; Garnica, A.; Cheung, S.W.; Beaudet, A.L. Prader-Willi phenotype caused by paternal deficiency for the HBII-85 C/D box small nucleolar RNA cluster. Nat. Genet. 2008, 40, 719-721. [CrossRef]

94. Duker, A.L.; Ballif, B.C.; Bawle, E.V.; Person, R.E.; Mahadevan, S.; Alliman, S.; Thompson, R.; Traylor, R.; Bejjani, B.A.; Shaffer, L.G.; et al. Paternally inherited microdeletion at 15q11.2 confirms a significant role for the SNORD116 C/D box snoRNA cluster in Prader-Willi syndrome. Eur. J. Hum. Genet. 2010, 18, 1196-1201. [CrossRef] [PubMed]

95. Tollervey, D.; Lehtonen, H.; Jansen, R.; Kern, H.; Hurt, E.C. Temperature-sensitive mutations demonstrate roles for yeast fibrillarin in pre-rRNA processing, pre-rRNA methylation, and ribosome assembly. Cell 1993, 72, 443-457. [CrossRef]

96. Jansen, R.P.; Hurt, E.C.; Kern, H.; Lehtonen, H.; Carmo-Fonseca, M.; Lapeyre, B.; Tollervey, D. Evolutionary conservation of the human nucleolar protein fibrillarin and its functional expression in yeast. J. Cell Biol. 1991, 113, 715-729. [CrossRef] [PubMed]

97. Amiri, K.A. Fibrillarin-like proteins occur in the domain Archaea. J. Bacteriol. 1994, 176, 2124-2127. [CrossRef] [PubMed]

98. Narcisi, E.M.; Glover, C.V.C.; Fechheimer, M. Fibrillarin, A Conserved Pre-ribosomal RNA Processing Protein of Giardia. J. Eukaryot. Microbiol. 1998, 45, 105-111. [CrossRef] [PubMed]

99. Rodriguez-Corona, U.; Sobol, M.; Rodriguez-Zapata, L.C.; Hozak, P.; Castano, E. Fibrillarin from Archaea to human. Biol. Cell 2015, 107, 159-174. [CrossRef] [PubMed]

100. Tessarz, P.; Santos-Rosa, H.; Robson, S.C.; Sylvestersen, K.B.; Nelson, C.J.; Nielsen, M.L.; Kouzarides, T. Glutamine methylation in histone H2A is an RNA-polymerase-I-dedicated modification. Nature 2014, 505, 564-568. [CrossRef]

101. Loza-Muller, L.; Rodríguez-Corona, U.; Sobol, M.; Rodríguez-Zapata, L.C.; Hozak, P.; Castano, E. Fibrillarin methylates H2A in RNA polymerase I trans-active promoters in Brassica oleracea. Front. Plant Sci. 2015, 6, 976. [CrossRef] 
102. Newton, K.; Petfalski, E.; Tollervey, D.; Cáceres, J.F. Fibrillarin Is Essential for Early Development and Required for Accumulation of an Intron-Encoded Small Nucleolar RNA in the Mouse. Mol. Cell. Biol. 2003, 23, 8519-8527. [CrossRef]

103. Bouffard, S.; Dambroise, E.; Brombin, A.; Lempereur, S.; Hatin, I.; Simion, M.; Corre, R.; Bourrat, F.; Joly, J.-S.; Jamen, F. Fibrillarin is essential for S-phase progression and neuronal differentiation in zebrafish dorsal midbrain and retina. Dev. Biol. 2018, 437, 1-16. [CrossRef]

104. Watanabe-Susaki, K.; Takada, H.; Enomoto, K.; Miwata, K.; Ishimine, H.; Intoh, A.; Ohtaka, M.; Nakanishi, M.; Sugino, H.; Asashima, M.; et al. Biosynthesis of ribosomal RNA in nucleoli regulates pluripotency and differentiation ability of pluripotent stem cells. Stem Cells 2014, 32, 3099-3111. [CrossRef] [PubMed]

105. Shubina, M.Y.; Musinova, Y.R.; Sheval, E.V. Proliferation, cancer, and aging-novel functions of the nucleolar methyltransferase fibrillarin? Cell Biol. Int. 2018, 42, 1463-1466. [CrossRef] [PubMed]

106. Ruggero, D.; Pandolfi, P.P. Does the ribosome translate cancer? Nat. Rev. Cancer 2003, 3, 179-192. [CrossRef]

107. White, R.J. RNA polymerases I and III, growth control and cancer. Nat. Rev. Mol. Cell Biol. 2005, 6, 69-78. [CrossRef] [PubMed]

108. Koh, C.M.; Gurel, B.; Sutcliffe, S.; Aryee, M.J.; Schultz, D.; Iwata, T.; Uemura, M.; Zeller, K.I.; Anele, U.; Zheng, Q.; et al. Alterations in nucleolar structure and gene expression programs in prostatic neoplasia are driven by the MYC oncogene. Am. J. Pathol. 2011, 178, 1824-1834. [CrossRef]

109. Marcel, V.; Ghayad, S.E.; Belin, S.; Therizols, G.; Morel, A.-P.; Solano-Gonzàlez, E.; Vendrell, J.A.; Hacot, S.; Mertani, H.C.; Albaret, M.A.; et al. p53 acts as a safeguard of translational control by regulating fibrillarin and rRNA methylation in cancer. Cancer Cell 2013, 24, 318-330. [CrossRef] [PubMed]

110. Su, H.; Xu, T.; Ganapathy, S.; Shadfan, M.; Long, M.; Huang, T.H.-M.; Thompson, I.; Yuan, Z.-M. Elevated snoRNA biogenesis is essential in breast cancer. Oncogene 2014, 33, 1348-1358. [CrossRef]

111. Derenzini, M.; Trerè, D.; Pession, A.; Montanaro, L.; Sirri, V.; Ochs, R.L. Nucleolar function and size in cancer cells. Am. J. Pathol. 1998, 152, 1291-1297.

112. Coller, H.A.; Grandori, C.; Tamayo, P.; Colbert, T.; Lander, E.S.; Eisenman, R.N.; Golub, T.R. Expression analysis with oligonucleotide microarrays reveals that MYC regulates genes involved in growth, cell cycle, signaling, and adhesion. Proc. Natl. Acad. Sci. USA 2000, 97, 3260-3265. [CrossRef]

113. Schlosser, I.; Hölzel, M.; Mürnseer, M.; Burtscher, H.; Weidle, U.H.; Eick, D. A role for c-Myc in the regulation of ribosomal RNA processing. Nucleic Acids Res. 2003, 31, 6148-6156. [CrossRef]

114. Imai, H.; Ochs, R.L.; Kiyosawa, K.; Furuta, S.; Nakamura, R.M.; Tan, E.M. Nucleolar antigens and autoantibodies in hepatocellular carcinoma and other malignancies. Am. J. Pathol. 1992, 140, 859-870. [PubMed]

115. Imai, H.; Kiyosawa, K.; Chan, E.K.; Tan, E.M. Autoantibodies in viral hepatitis-related hepatocellular carcinoma. Intervirology 1993, 35, 73-85. [CrossRef]

116. Covini, G.; von Mühlen, C.A.; Pacchetti, S.; Colombo, M.; Chan, E.K.; Tan, E.M. Diversity of antinuclear antibody responses in hepatocellular carcinoma. J. Hepatol. 1997, 26, 1255-1265. [CrossRef]

117. El Hassouni, B.; Sarkisjan, D.; Vos, J.C.; Giovannetti, E.; Peters, G.J. Targeting the ribosome biogenesis key molecule fibrillarin to avoid chemoresistance. Curr. Med. Chem. 2018. [CrossRef] [PubMed]

118. Zhou, X.; Tan, F.K.; Xiong, M.; Milewicz, D.M.; Feghali, C.A.; Fritzler, M.J.; Reveille, J.D.; Arnett, F.C. Systemic Sclerosis (Scleroderma): Specific Autoantigen Genes Are Selectively Overexpressed in Scleroderma Fibroblasts. J. Immunol. 2001, 167, 7126-7133. [CrossRef] [PubMed]

119. Lischwe, M.A.; Ochs, R.L.; Reddy, R.; Cook, R.G.; Yeoman, L.C.; Tan, E.M.; Reichlin, M.; Busch, H. Purification and partial characterization of a nucleolar scleroderma antigen $(\mathrm{Mr}=34,000 ; \mathrm{pI}, 8.5)$ rich in NG,NG-dimethylarginine. J. Biol. Chem. 1985, 260, 14304-14310. [PubMed]

120. Ochs, R.L.; Lischwe, M.A.; Spohn, W.H.; Busch, H. Fibrillarin: A new protein of the nucleolus identified by autoimmune sera. Biol. Cell 1985, 54, 123-133. [CrossRef]

121. Busch, H.; Busch, R.K.; Black, A.; Chan, P.K.; Chatterjee, A.; Durban, E.; Freeman, J.; Ochs, R.; Reichlin, M.; Tan, E.M. Novel nucleolar antigens in autoimmune disease. J. Rheumatol. Suppl. 1987, 14 (Suppl. 13), 70-77.

122. Reimer, G.; Steen, V.D.; Penning, C.A.; Medsger, T.A., Jr; Tan, E.M. Correlates between autoantibodies to nucleolar antigens and clinical features in patients with systemic sclerosis (scleroderma). Arthritis Rheum. 1988, 31, 525-532. [CrossRef]

123. Pollard, K.M.; Reimer, G.; Tan, E.M. Autoantibodies in scleroderma. Clin. Exp. Rheumatol. 1989, 7 (Suppl. 3), S57-S62. 
124. Kühn, G.; Jarzabek-Chorzelska, M.; Blaszczyk, M.; Chorzelski, T.P.; Jablonska, S. [The fibrillarin (Scl-34) autoantibody in systemic scleroderma]. Dermatol. Monatsschr. 1990, 176, 19-26.

125. Arnett, F.C.; Reveille, J.D.; Goldstein, R.; Pollard, K.M.; Leaird, K.; Smith, E.A.; Leroy, E.C.; Fritzler, M.J. Autoantibodies to fibrillarin in systemic sclerosis (scleroderma). An immunogenetic, serologic, and clinical analysis. Arthritis Rheum. 1996, 39, 1151-1160. [CrossRef] [PubMed]

126. von Mühlen, C.A.; Tan, E.M. Autoantibodies in the diagnosis of systemic rheumatic diseases. Semin. Arthritis Rheum. 1995, 24, 323-358. [CrossRef]

127. Boonstra, M.; Mertens, B.J.A.; Bakker, J.A.; Ninaber, M.K.; Ajmone Marsan, N.; van der Helm-van Mil, A.H.M.; Scherer, H.U.; Huizinga, T.W.J.; de Vries-Bouwstra, J.K. To what extent do autoantibodies help to identify high-risk patients in systemic sclerosis? Clin. Exp. Rheumatol. 2018, 36 (Suppl. 113), 109-117.

128. Ferri, C.; Emdin, M.; Storino, F.A.; Giuggioli, D.; Longombardo, G.; Greco, F.; Fertig, N.; Medsger, T.A. Isolated pulmonary hypertension in diffuse cutaneous systemic sclerosis successfully treated with long-term plasma exchange. Scand. J. Rheumatol. 2000, 29, 198-200. [PubMed]

129. Kasturi, K.N.; Hatakeyama, A.; Spiera, H.; Bona, C.A. Antifibrillarin autoantibodies present in systemic sclerosis and other connective tissue diseases interact with similar epitopes. J. Exp. Med. 1995, 181, 1027-1036. [CrossRef] [PubMed]

130. Bae, S.-C.; Lee, Y.H. Meta-analysis of gene expression profiles of peripheral blood cells in systemic lupus erythematosus. Cell. Mol. Biol. 2018, 64, 40-49. [CrossRef] [PubMed]

131. Pellizzoni, L.; Baccon, J.; Charroux, B.; Dreyfuss, G. The survival of motor neurons (SMN) protein interacts with the snoRNP proteins fibrillarin and GAR1. Curr. Biol. 2001, 11, 1079-1088. [CrossRef]

132. Jones, K.W.; Gorzynski, K.; Hales, C.M.; Fischer, U.; Badbanchi, F.; Terns, R.M.; Terns, M.P. Direct interaction of the spinal muscular atrophy disease protein SMN with the small nucleolar RNA-associated protein fibrillarin. J. Biol. Chem. 2001, 276, 38645-38651. [CrossRef]

133. Lefebvre, S.; Bürglen, L.; Reboullet, S.; Clermont, O.; Burlet, P.; Viollet, L.; Benichou, B.; Cruaud, C.; Millasseau, P.; Zeviani, M. Identification and characterization of a spinal muscular atrophy-determining gene. Cell 1995, 80, 155-165. [CrossRef]

134. Lefebvre, S.; Burlet, P.; Liu, Q.; Bertrandy, S.; Clermont, O.; Munnich, A.; Dreyfuss, G.; Melki, J. Correlation between severity and SMN protein level in spinal muscular atrophy. Nat. Genet. 1997, 16, 265-269. [CrossRef] [PubMed]

135. Liu, Q.; Dreyfuss, G. A novel nuclear structure containing the survival of motor neurons protein. EMBO J. 1996, 15, 3555-3565. [CrossRef] [PubMed]

136. Béchade, C.; Rostaing, P.; Cisterni, C.; Kalisch, R.; La Bella, V.; Pettmann, B.; Triller, A. Subcellular distribution of survival motor neuron (SMN) protein: Possible involvement in nucleocytoplasmic and dendritic transport. Eur. J. Neurosci. 1999, 11, 293-304. [CrossRef] [PubMed]

137. Young, P.J.; Le, T.T.; Dunckley, M.; Nguyen, T.M.; Burghes, A.H.; Morris, G.E. Nuclear gems and Cajal (coiled) bodies in fetal tissues: Nucleolar distribution of the spinal muscular atrophy protein, SMN. Exp. Cell Res. 2001, 265, 252-261. [CrossRef]

138. Todd, A.G.; Morse, R.; Shaw, D.J.; Stebbings, H.; Young, P.J. Analysis of SMN-neurite granules: Core Cajal body components are absent from SMN-cytoplasmic complexes. Biochem. Biophys. Res. Commun. 2010, 397, 479-485. [CrossRef] [PubMed]

139. Pellizzoni, L.; Charroux, B.; Rappsilber, J.; Mann, M.; Dreyfuss, G. A functional interaction between the survival motor neuron complex and RNA polymerase II. J. Cell Biol. 2001, 152, 75-85. [CrossRef]

140. Calle, E.; Berciano, M.T.; Fernández, R.; Lafarga, M. Activation of the autophagy, c-FOS and ubiquitin expression, and nucleolar alterations in Schwann cells precede demyelination in tellurium-induced neuropathy. Acta Neuropathol. 1999, 97, 143-155. [CrossRef] [PubMed]

141. Sornjai, W.; Lithanatudom, P.; Erales, J.; Joly, P.; Francina, A.; Hacot, S.; Fucharoen, S.; Svasti, S.; Diaz, J.J.; Mertani, H.C.; et al. Hypermethylation of $28 \mathrm{~S}$ ribosomal RNA in $\beta$-thalassemia trait carriers. Int. J. Biol. Macromol. 2017, 94, 728-734. [CrossRef]

142. Lai, C.-W.; Chen, H.-L.; Lin, K.-Y.; Liu, F.-C.; Chong, K.-Y.; Cheng, W.T.K.; Chen, C.-M. FTSJ2, a heat shock-inducible mitochondrial protein, suppresses cell invasion and migration. PLoS ONE 2014, 9, e90818. [CrossRef] 
143. Campbell, J.M.; Lockwood, W.W.; Buys, T.P.H.; Chari, R.; Coe, B.P.; Lam, S.; Lam, W.L. Integrative genomic and gene expression analysis of chromosome 7 identified novel oncogene loci in non-small cell lung cancer. Genome 2008, 51, 1032-1039. [CrossRef] [PubMed]

144. Reddy, R.; Singh, R.; Shimba, S. Methylated cap structures in eukaryotic RNAs: Structure, synthesis and functions. Pharmacol. Ther. 1992, 54, 249-267. [CrossRef]

145. Kuge, H.; Brownlee, G.G.; Gershon, P.D.; Richter, J.D. Cap ribose methylation of c-mos mRNA stimulates translation and oocyte maturation in Xenopus laevis. Nucleic Acids Res. 1998, 26, 3208-3214. [CrossRef] [PubMed]

146. Shuman, S. What messenger RNA capping tells us about eukaryotic evolution. Nat. Rev. Mol. Cell Biol. 2002, 3, 619-625. [CrossRef]

147. Gu, M.; Lima, C.D. Processing the message: Structural insights into capping and decapping mRNA. Curr. Opin. Struct. Biol. 2005, 15, 99-106. [CrossRef] [PubMed]

148. Ramanathan, A.; Robb, G.B.; Chan, S.-H. mRNA capping: Biological functions and applications. Nucleic Acids Res. 2016, 44, 7511-7526. [CrossRef] [PubMed]

149. Inesta-Vaquera, F.; Chaugule, V.K.; Galloway, A.; Chandler, L.; Rojas-Fernandez, A.; Weidlich, S.; Peggie, M.; Cowling, V.H. DHX15 regulates CMTR1-dependent gene expression and cell proliferation. Life Sci Alliance 2018, 1, e201800092. [CrossRef] [PubMed]

150. Aregger, M.; Cowling, V.H. Regulation of mRNA capping in the cell cycle. RNA Biol. 2017, 14, 11-14. [CrossRef]

151. Bélanger, F.; Stepinski, J.; Darzynkiewicz, E.; Pelletier, J. Characterization of hMTr1, a human Cap1 2'-O-ribose methyltransferase. J. Biol. Chem. 2010, 285, 33037-33044. [CrossRef]

152. Perry, R.P.; Kelley, D.E. Kinetics of formation of $5^{\prime}$ terminal caps in mRNA. Cell 1976, 8, 433-442. [CrossRef]

153. Werner, M.; Purta, E.; Kaminska, K.H.; Cymerman, I.A.; Campbell, D.A.; Mittra, B.; Zamudio, J.R.; Sturm, N.R.; Jaworski, J.; Bujnicki, J.M. 2'-O-ribose methylation of cap2 in human: Function and evolution in a horizontally mobile family. Nucleic Acids Res. 2011, 39, 4756-4768. [CrossRef]

154. Banerjee, A.K. 5'-terminal cap structure in eucaryotic messenger ribonucleic acids. Microbiol. Rev. 1980, 44, $175-205$. [PubMed]

155. Smietanski, M.; Werner, M.; Purta, E.; Kaminska, K.H.; Stepinski, J.; Darzynkiewicz, E.; Nowotny, M.; Bujnicki, J.M. Structural analysis of human 2'-O-ribose methyltransferases involved in mRNA cap structure formation. Nat. Commun. 2014, 5, 3004. [CrossRef]

156. Dahlin, A.; Denny, J.; Roden, D.M.; Brilliant, M.H.; Ingram, C.; Kitchner, T.E.; Linneman, J.G.; Shaffer, C.M.; Weeke, P.; Xu, H.; et al. CMTR1 is associated with increased asthma exacerbations in patients taking inhaled corticosteroids. Immun. Inflamm. Dis. 2015, 3, 350-359. [CrossRef] [PubMed]

157. Daffis, S.; Szretter, K.J.; Schriewer, J.; Li, J.; Youn, S.; Errett, J.; Lin, T.-Y.; Schneller, S.; Zust, R.; Dong, H.; et al. 2'-O methylation of the viral mRNA cap evades host restriction by IFIT family members. Nature 2010, 468, 452-456. [CrossRef] [PubMed]

158. Züst, R.; Cervantes-Barragan, L.; Habjan, M.; Maier, R.; Neuman, B.W.; Ziebuhr, J.; Szretter, K.J.; Baker, S.C.; Barchet, W.; Diamond, M.S.; et al. Ribose 2'-O-methylation provides a molecular signature for the distinction of self and non-self mRNA dependent on the RNA sensor Mda5. Nat. Immunol. 2011, 12, 137-143. [CrossRef] [PubMed]

159. Kumar, P.; Sweeney, T.R.; Skabkin, M.A.; Skabkina, O.V.; Hellen, C.U.T.; Pestova, T.V. Inhibition of translation by IFIT family members is determined by their ability to interact selectively with the $5^{\prime}$-terminal regions of cap0-, cap1- and 5'ppp- mRNAs. Nucleic Acids Res. 2014, 42, 3228-3245. [CrossRef] [PubMed]

160. Diamond, M.S. IFIT1: A dual sensor and effector molecule that detects non-2'-O methylated viral RNA and inhibits its translation. Cytokine Growth Factor Rev. 2014, 25, 543-550. [CrossRef] [PubMed]

161. Abbas, Y.M.; Laudenbach, B.T.; Martínez-Montero, S.; Cencic, R.; Habjan, M.; Pichlmair, A.; Damha, M.J.; Pelletier, J.; Nagar, B. Structure of human IFIT1 with capped RNA reveals adaptable mRNA binding and mechanisms for sensing N1 and N2 ribose 2'-O methylations. Proc. Natl. Acad. Sci. USA 2017, 114, E2106-E2115. [CrossRef]

162. Jackson, D.J.; Sykes, A.; Mallia, P.; Johnston, S.L. Asthma exacerbations: Origin, effect, and prevention. J. Allergy Clin. Immunol. 2011, 128, 1165-1174. [CrossRef]

163. Geiss, G.K.; Carter, V.S.; He, Y.; Kwieciszewski, B.K.; Holzman, T.; Korth, M.J.; Lazaro, C.A.; Fausto, N.; Bumgarner, R.E.; Katze, M.G. Gene expression profiling of the cellular transcriptional network regulated by 
alpha/beta interferon and its partial attenuation by the hepatitis $C$ virus nonstructural 5A protein. J. Virol. 2003, 77, 6367-6375. [CrossRef]

164. Haline-Vaz, T.; Silva, T.C.L.; Zanchin, N.I.T. The human interferon-regulated ISG95 protein interacts with RNA polymerase II and shows methyltransferase activity. Biochem. Biophys. Res. Commun. 2008, 372, 719-724. [CrossRef] [PubMed]

165. Tan, W.C. Viruses in asthma exacerbations. Curr. Opin. Pulm. Med. 2005, 11, 21-26. [CrossRef]

166. World Health Organization. Bulletin of WHO Vol. 90 No. 02 2012; World Health Organization: Geneva, Switzerland, 2012; ISBN 9789240689718.

167. Ardura-Fabregat, A.; Boddeke, E.W.G.M.; Boza-Serrano, A.; Brioschi, S.; Castro-Gomez, S.; Ceyzériat, K.; Dansokho, C.; Dierkes, T.; Gelders, G.; Heneka, M.T.; et al. Targeting Neuroinflammation to Treat Alzheimer's Disease. CNS Drugs 2017, 31, 1057-1082. [CrossRef] [PubMed]

168. Boza-Serrano, A.; Yang, Y.; Paulus, A.; Deierborg, T. Innate immune alterations are elicited in microglial cells before plaque deposition in the Alzheimer's disease mouse model 5xFAD. Sci. Rep. 2018, 8, 1550. [CrossRef] [PubMed]

169. Banerjee, S.; Tian, T.; Wei, Z.; Peck, K.N.; Shih, N.; Chalian, A.A.; O'Malley, B.W.; Weinstein, G.S.; Feldman, M.D.; Alwine, J.; et al. Microbial Signatures Associated with Oropharyngeal and Oral Squamous Cell Carcinomas. Sci. Rep. 2017, 7, 4036. [CrossRef] [PubMed]

170. Vicente, C.; Schwab, C.; Broux, M.; Geerdens, E.; Degryse, S.; Demeyer, S.; Lahortiga, I.; Elliott, A.; Chilton, L.; La Starza, R.; et al. Targeted sequencing identifies associations between IL7R-JAK mutations and epigenetic modulators in T-cell acute lymphoblastic leukemia. Haematologica 2015, 100, 1301-1310. [CrossRef]

171. Degryse, S.; Cools, J. JAK kinase inhibitors for the treatment of acute lymphoblastic leukemia. J. Hematol. Oncol. 2015, 8, 91. [CrossRef] [PubMed]

172. Degryse, S.; de Bock, C.E.; Demeyer, S.; Govaerts, I.; Bornschein, S.; Verbeke, D.; Jacobs, K.; Binos, S.; Skerrett-Byrne, D.A.; Murray, H.C.; et al. Mutant JAK3 phosphoproteomic profiling predicts synergism between JAK3 inhibitors and MEK/BCL2 inhibitors for the treatment of T-cell acute lymphoblastic leukemia. Leukemia 2018, 32, 788-800. [CrossRef]

173. Jemal, A.; Center, M.M.; DeSantis, C.; Ward, E.M. Global patterns of cancer incidence and mortality rates and trends. Cancer Epidemiol. Biomark. Prev. 2010, 19, 1893-1907. [CrossRef]

174. Siegel, R.L.; Miller, K.D.; Jemal, A. Cancer statistics, 2015. CA Cancer J. Clin. 2015, 65, 5-29. [CrossRef]

175. Devarakonda, S.; Morgensztern, D.; Govindan, R. Genomic alterations in lung adenocarcinoma. Lancet Oncol. 2015, 16, e342-e351. [CrossRef]

176. Soda, M.; Choi, Y.L.; Enomoto, M.; Takada, S.; Yamashita, Y.; Ishikawa, S.; Fujiwara, S.-I.; Watanabe, H.; Kurashina, K.; Hatanaka, H.; et al. Identification of the transforming EML4-ALK fusion gene in non-small-cell lung cancer. Nature 2007, 448, 561-566. [CrossRef]

177. Wen, M.; Wang, X.; Sun, Y.; Xia, J.; Fan, L.; Xing, H.; Zhang, Z.; Li, X. Detection of EML4-ALK fusion gene and features associated with EGFR mutations in Chinese patients with non-small-cell lung cancer. Onco Targets Ther. 2016, 9, 1989-1995. [CrossRef]

178. Du, X.; Shao, Y.; Qin, H.-F.; Tai, Y.-H.; Gao, H.-J. ALK-rearrangement in non-small-cell lung cancer (NSCLC). Thorac. Cancer 2018, 9, 423-430. [CrossRef] [PubMed]

179. Hoskins, A.A.; Moore, M.J. The spliceosome: A flexible, reversible macromolecular machine. Trends Biochem. Sci. 2012, 37, 179-188. [CrossRef] [PubMed]

180. Bohnsack, M.T.; Sloan, K.E. Modifications in small nuclear RNAs and their roles in spliceosome assembly and function. Biol. Chem. 2018, 399, 1265-1276. [CrossRef]

181. Karijolich, J.; Yu, Y.-T. Spliceosomal snRNA modifications and their function. RNA Biol. 2010, 7, $192-204$. [CrossRef]

182. Dönmez, G.; Hartmuth, K.; Lührmann, R. Modified nucleotides at the $5^{\prime}$ end of human U2 snRNA are required for spliceosomal E-complex formation. RNA 2004, 10, 1925-1933. [CrossRef]

183. Jia, Y.; Mu, J.C.; Ackerman, S.L. Mutation of a U2 snRNA gene causes global disruption of alternative splicing and neurodegeneration. Cell 2012, 148, 296-308. [CrossRef]

184. Mao, Y.S.; Zhang, B.; Spector, D.L. Biogenesis and function of nuclear bodies. Trends Genet. 2011, 27, $295-306$. [CrossRef]

185. Massenet, S.; Bertrand, E.; Verheggen, C. Assembly and trafficking of box C/D and H/ACA snoRNPs. RNA Biol. 2017, 14, 680-692. [CrossRef] 
186. Meier, U.T. RNA modification in Cajal bodies. RNA Biol. 2017, 14, 693-700. [CrossRef] [PubMed]

187. Jády, B.E.; Kiss, T. A small nucleolar guide RNA functions both in $2^{\prime}$-O-ribose methylation and pseudouridylation of the U5 spliceosomal RNA. EMBO J. 2001, 20, 541-551. [CrossRef] [PubMed]

188. Kishore, S.; Gruber, A.R.; Jedlinski, D.J.; Syed, A.P.; Jorjani, H.; Zavolan, M. Insights into snoRNA biogenesis and processing from PAR-CLIP of snoRNA core proteins and small RNA sequencing. Genome Biol. 2013, 14, R45. [CrossRef] [PubMed]

189. Deryusheva, S.; Gall, J.G. scaRNAs and snoRNAs: Are they limited to specific classes of substrate RNAs? RNA 2018, 25, 17-22. [CrossRef]

190. Raj, B.; Blencowe, B.J. Alternative Splicing in the Mammalian Nervous System: Recent Insights into Mechanisms and Functional Roles. Neuron 2015, 87, 14-27. [CrossRef]

191. Patil, P.; Kibiryeva, N.; Uechi, T.; Marshall, J.; O’Brien, J.E., Jr; Artman, M.; Kenmochi, N.; Bittel, D.C. scaRNAs regulate splicing and vertebrate heart development. Biochim. Biophys. Acta 2015, 1852, 1619-1629. [CrossRef]

192. Nagasawa, C.; Ogren, A.; Kibiryeva, N.; Marshall, J.; O’Brien, J.E.; Kenmochi, N.; Bittel, D.C. The Role of scaRNAs in Adjusting Alternative mRNA Splicing in Heart Development. J. Cardiovasc. Dev. Dis. 2018, 5, 26. [CrossRef]

193. Carlile, T.M.; Rojas-Duran, M.F.; Zinshteyn, B.; Shin, H.; Bartoli, K.M.; Gilbert, W.V. Pseudouridine profiling reveals regulated mRNA pseudouridylation in yeast and human cells. Nature 2014, 515, 143-146. [CrossRef]

194. Lovejoy, A.F.; Riordan, D.P.; Brown, P.O. Transcriptome-wide mapping of pseudouridines: Pseudouridine synthases modify specific mRNAs in S. cerevisiae. PLoS ONE 2014, 9, e110799. [CrossRef]

195. Schwartz, S.; Bernstein, D.A.; Mumbach, M.R.; Jovanovic, M.; Herbst, R.H.; León-Ricardo, B.X.; Engreitz, J.M.; Guttman, M.; Satija, R.; Lander, E.S.; et al. Transcriptome-wide mapping reveals widespread dynamic-regulated pseudouridylation of ncRNA and mRNA. Cell 2014, 159, 148-162. [CrossRef] [PubMed]

196. Beckmann, B.M.; Horos, R.; Fischer, B.; Castello, A.; Eichelbaum, K.; Alleaume, A.-M.; Schwarzl, T.; Curk, T.; Foehr, S.; Huber, W.; et al. The RNA-binding proteomes from yeast to man harbour conserved enigmRBPs. Nat. Commun. 2015, 6, 10127. [CrossRef] [PubMed]

197. Clouet d'Orval, B.; Bortolin, M.L.; Gaspin, C.; Bachellerie, J.P. Box C/D RNA guides for the ribose methylation of archaeal tRNAs. The tRNATrp intron guides the formation of two ribose-methylated nucleosides in the mature tRNATrp. Nucleic Acids Res. 2001, 29, 4518-4529. [CrossRef] [PubMed]

198. Kristen M Bartoli, Cassandra Schaening, Thomas Carlile, Wendy V Gilbert Conserved Methyltransferase Spb1 Targets mRNAs for Regulated Modification with 2'-O-Methyl Ribose. bioRxiv 2018. [CrossRef]

199. Baltz, A.G.; Munschauer, M.; Schwanhäusser, B.; Vasile, A.; Murakawa, Y.; Schueler, M.; Youngs, N.; Penfold-Brown, D.; Drew, K.; Milek, M.; et al. The mRNA-bound proteome and its global occupancy profile on protein-coding transcripts. Mol. Cell 2012, 46, 674-690. [CrossRef] [PubMed]

200. Castello, A.; Fischer, B.; Eichelbaum, K.; Horos, R.; Beckmann, B.M.; Strein, C.; Davey, N.E.; Humphreys, D.T.; Preiss, T.; Steinmetz, L.M.; et al. Insights into RNA biology from an atlas of mammalian mRNA-binding proteins. Cell 2012, 149, 1393-1406. [CrossRef] [PubMed]

201. Ringeard, M.; Marchand, V.; Decroly, E.; Motorin, Y.; Bennasser, Y. FTSJ3 is an RNA 2'-O-methyltransferase recruited by HIV to avoid innate immune sensing. Nature 2019, 565, 500-504. [CrossRef]

202. Choi, J.; Indrisiunaite, G.; DeMirci, H.; Ieong, K.-W.; Wang, J.; Petrov, A.; Prabhakar, A.; Rechavi, G.; Dominissini, D.; He, C.; et al. 2'-O-methylation in mRNA disrupts tRNA decoding during translation elongation. Nat. Struct. Mol. Biol. 2018, 25, 208-216. [CrossRef]

203. Costa, M.C.; Leitão, A.L.; Enguita, F.J. Biogenesis and mechanism of action of small non-coding RNAs: Insights from the point of view of structural biology. Int. J. Mol. Sci. 2012, 13, 10268-10295. [CrossRef]

204. Olina, A.V.; Kulbachinskiy, A.V.; Aravin, A.A.; Esyunina, D.M. Argonaute Proteins and Mechanisms of RNA Interference in Eukaryotes and Prokaryotes. Biochemistry 2018, 83, 483-497. [CrossRef]

205. Cox, D.N.; Chao, A.; Baker, J.; Chang, L.; Qiao, D.; Lin, H. A novel class of evolutionarily conserved genes defined by piwi are essential for stem cell self-renewal. Genes Dev. 1998, 12, 3715-3727. [CrossRef] [PubMed]

206. Deng, W.; Lin, H. Miwi, a murine homolog of piwi, encodes a cytoplasmic protein essential for spermatogenesis. Dev. Cell 2002, 2, 819-830. [CrossRef]

207. Vagin, V.V.; Sigova, A.; Li, C.; Seitz, H.; Gvozdev, V.; Zamore, P.D. A distinct small RNA pathway silences selfish genetic elements in the germline. Science 2006, 313, 320-324. [CrossRef] 
208. Brennecke, J.; Aravin, A.A.; Stark, A.; Dus, M.; Kellis, M.; Sachidanandam, R.; Hannon, G.J. Discrete small RNA-generating loci as master regulators of transposon activity in Drosophila. Cell 2007, 128, 1089-1103. [CrossRef] [PubMed]

209. Kirino, Y.; Mourelatos, Z. 2'-O-methyl modification in mouse piRNAs and its methylase. Nucleic Acids Symp. Ser. 2007, 417-418. [CrossRef]

210. Juliano, C.; Wang, J.; Lin, H. Uniting germline and stem cells: The function of Piwi proteins and the piRNA pathway in diverse organisms. Annu. Rev. Genet. 2011, 45, 447-469. [CrossRef] [PubMed]

211. Plotnikova, A.; Baranauskè, S.; Osipenko, A.; Klimašauskas, S.; Vilkaitis, G. Mechanistic insights into small RNA recognition and modification by the HEN1 methyltransferase. Biochem. J. 2013, 453, 281-290. [CrossRef]

212. Lim, S.L.; Qu, Z.P.; Kortschak, R.D.; Lawrence, D.M.; Geoghegan, J.; Hempfling, A.-L.; Bergmann, M.; Goodnow, C.C.; Ormandy, C.J.; Wong, L.; et al. HENMT1 and piRNA Stability Are Required for Adult Male Germ Cell Transposon Repression and to Define the Spermatogenic Program in the Mouse. PLoS Genet. 2015, 11, e1005620.

213. Hempfling, A.L.; Lim, S.L.; Adelson, D.L.; Evans, J.; O'Connor, A.E.; Qu, Z.P.; Kliesch, S.; Weidner, W.; O'Bryan, M.K.; Bergmann, M. Expression patterns of HENMT1 and PIWIL1 in human testis: Implications for transposon expression. Reproduction 2017, 154, 363-374. [CrossRef]

214. Hoff, A.M.; Alagaratnam, S.; Zhao, S.; Bruun, J.; Andrews, P.W.; Lothe, R.A.; Skotheim, R.I. Identification of Novel Fusion Genes in Testicular Germ Cell Tumors. Cancer Res. 2016, 76, 108-116. [CrossRef]

215. Peng, J.C.; Lin, H. Beyond transposons: The epigenetic and somatic functions of the Piwi-piRNA mechanism. Curr. Opin. Cell Biol. 2013, 25, 190-194. [CrossRef] [PubMed]

216. Martinez, V.D.; Vucic, E.A.; Thu, K.L.; Hubaux, R.; Enfield, K.S.S.; Pikor, L.A.; Becker-Santos, D.D.; Brown, C.J.; Lam, S.; Lam, W.L. Unique somatic and malignant expression patterns implicate PIWI-interacting RNAs in cancer-type specific biology. Sci. Rep. 2015, 5, 10423. [CrossRef]

217. Ponnusamy, M.; Yan, K.-W.; Liu, C.-Y.; Li, P.-F.; Wang, K. PIWI family emerging as a decisive factor of cell fate: An overview. Eur. J. Cell Biol. 2017, 96, 746-757. [CrossRef] [PubMed]

218. Lim, R.S.M.; Anand, A.; Nishimiya-Fujisawa, C.; Kobayashi, S.; Kai, T. Analysis of Hydra PIWI proteins and piRNAs uncover early evolutionary origins of the piRNA pathway. Dev. Biol. 2014, 386, 237-251. [CrossRef] [PubMed]

219. Lewis, S.H.; Quarles, K.A.; Yang, Y.; Tanguy, M.; Frézal, L.; Smith, S.A.; Sharma, P.P.; Cordaux, R.; Gilbert, C.; Giraud, I.; et al. Pan-arthropod analysis reveals somatic piRNAs as an ancestral defence against transposable elements. Nat. Ecol. Evol. 2018, 2, 174-181. [CrossRef] [PubMed]

220. Rajasethupathy, P.; Antonov, I.; Sheridan, R.; Frey, S.; Sander, C.; Tuschl, T.; Kandel, E.R. A role for neuronal piRNAs in the epigenetic control of memory-related synaptic plasticity. Cell 2012, 149, 693-707. [CrossRef] [PubMed]

221. Abe, M.; Naqvi, A.; Hendriks, G.-J.; Feltzin, V.; Zhu, Y.; Grigoriev, A.; Bonini, N.M. Impact of age-associated increase in 2'-O-methylation of miRNAs on aging and neurodegeneration in Drosophila. Genes Dev. 2014, 28, 44-57. [CrossRef]

222. Pepper, A.S.-R.; Beerman, R.W.; Bhogal, B.; Jongens, T.A. Argonaute2 suppresses Drosophila fragile $X$ expression preventing neurogenesis and oogenesis defects. PLoS ONE 2009, 4, e7618. [CrossRef]

(C) 2019 by the authors. Licensee MDPI, Basel, Switzerland. This article is an open access article distributed under the terms and conditions of the Creative Commons Attribution (CC BY) license (http://creativecommons.org/licenses/by/4.0/). 